\title{
Mechanical-biological treatment: Performance and potentials. An LCA of 8 MBT plants including waste characterization
}

\author{
Montejo, Cristina; Tonini, Davide; Márquez, María del Carmen; Astrup, Thomas Fruergaard
}

Published in:

Journal of Environmental Management

Link to article, DOI:

10.1016/j.jenvman.2013.05.063

Publication date:

2013

Document Version

Peer reviewed version

Link back to DTU Orbit

Citation (APA):

Montejo, C., Tonini, D., Márquez, M. D. C., \& Astrup, T. F. (2013). Mechanical-biological treatment:

Performance and potentials. An LCA of 8 MBT plants including waste characterization. Journal of Environmental Management, 128, 661-673. https://doi.org/10.1016/j.jenvman.2013.05.063

\section{General rights}

Copyright and moral rights for the publications made accessible in the public portal are retained by the authors and/or other copyright owners and it is a condition of accessing publications that users recognise and abide by the legal requirements associated with these rights.

- Users may download and print one copy of any publication from the public portal for the purpose of private study or research.

- You may not further distribute the material or use it for any profit-making activity or commercial gain

- You may freely distribute the URL identifying the publication in the public portal 


\title{
Mechanical-biological treatment: Performance and potentials. An LCA of 8 MBT plants including waste characterization
}

\author{
Montejo, C.; Tonini, D.; Márquez, M. C.; Astrup, T. F. \\ * Corresponding author: dait@env.dtu.dk
}

Phone: 004545251699

\section{Accepted version of the article:}

Montejo, C.; Tonini, D.; Márquez, M. C.; Astrup, T. F. Mechanical-biological treatment: Performance and potentials. An LCA of 8 MBT plants including waste characterization. J. Environ. Manage. 2013, 128, 661-673.

This version did not undergo proof-reading and final journal editing. When referring to this work, please cite the journal publication stated above. 


\section{Highlights:}

$\checkmark$ We assessed the environmental performances of 8 MBT-based management systems

$\checkmark$ Environmental performance was directly related to materials and energy recovery

$\checkmark$ For the OFMSW, anaerobic digestion was favourable over direct composting

$\checkmark$ Optimization of materials and biogas-energy recovery are recommended

$\checkmark$ Optimal RDF management depends on marginal energy assumptions and C sequestration 


\section{Mechanical-biological treatment: performance and potentials. A LCA of 8 MBT plants including waste characterization}

${\text { Cristina Montejo } *^{\mathrm{a}}, \text { Davide Tonini }}^{\mathrm{b}}$, María del Carmen Márquez ${ }^{\mathrm{a}}$, Thomas Astrup ${ }^{\mathrm{b}}$

${ }^{a}$ Department of Chemical Engineering, University of Salamanca, Plaza de los Caídos 15, 37008 Salamanca, Spain.

${ }^{\mathrm{b}}$ Department of Environmental Engineering, Technical University of Denmark, Miljoevej, Building 115, 2800 Kgs. Lyngby, Denmark.

*Corresponding author. Tel: +34 923294 479; Fax: +34 923294 574. E-mail: cmontejo@usal.es 


\begin{abstract}
In the endeavour of avoiding presence of biodegradable waste in landfills and increasing recycling, mechanical-biological treatment (MBT) plants have seen a significant increase in number and capacity in the last two decades. The aim of these plants is separating and stabilizing the quickly biodegradable fraction of the waste as well as recovering recyclables from mixed waste streams. In this study the environmental performance of eight MBT-based waste management scenarios in Spain was assessed by means of life cycle assessment. The focus was on the technical and environmental performance of the MBT plants. These widely differed in type of biological treatment and recovery efficiencies. The results indicated that the performance is strongly connected with energy and materials recovery efficiency. The recommendation for upgrading and/or commissioning of future plants is to optimize materials recovery through increased automation of the selection and to prioritize biogas-electricity production from the organic fraction over direct composting. The optimal strategy for refuse derived fuel (RDF) management depends upon the environmental compartment to be prioritized and the type of marginal electricity source in the system. It was estimated that, overall, up to ca. $180-190 \mathrm{kt} \mathrm{CO}_{2}$-eq. $\mathrm{y}^{-1}$ may be saved by optimizing the MBT plants under assessment.
\end{abstract}

Keywords: MBT, LCA, waste composition, biological treatment, material recovery, RDF 


\section{Glossary:}

AC: Acidification

ECS: Eddy current system

ETs: Ecotoxicity in soil

ETwc: Ecotoxicity in water (chronic)

GHG: Greenhouse gas

GW: Global warming

HDPE: High density polyethylene

HTa: Human toxicity via air

HTs: Human toxicity via soil

HTw: Human toxicity via water

HRT: Hydraulic retention time

LCA: Life cycle assessment

LDPE: Low density polyethylene

MBP: Mechanical-biological pretreatment

MBS: Mechanical-biological stabilization

MBT: Mechanical-biological treatment

MBTP: Mechanical-biological treatment plant

MSW: Municipal solid waste

NE: Nutrient enrichment

OFMSW: Organic fraction of municipal solid waste

PET: Polyethylene terephthalate.

POF: Photochemical ozone formation

RDF: Refuse derived fuel

rMSW: Residual municipal solid waste

SGR: Spoiled groundwater resources

SOD: Stratospheric ozone depletion

VOCs: Volatile organic compounds

VS: Volatile solids

WEEE: Waste electrical and electronic equipment ww: wet waste 


\section{Introduction}

From 1990 to 2010, about 180 MBT plants have been installed in Europe (ECN, 2009) with the aim of avoiding the presence of biodegradable waste in landfills, according to the European Directive 1999/31/CE (CEC, 1999). These plants combine mechanical separation of different fractions contained in household waste with stabilization of organic matter by means of biological processes such as anaerobic digestion or composting. According to Bilitewski et al. (2011), two main types of MBT technology exist: A) mechanical-biological pretreatment (MBP), where the organic fraction is separated and biologically stabilized prior to landfilling and recyclables as well as RDF are recovered from the residual coarse fraction, and B) mechanical-biological stabilization (MBS) or biodrying, which first composts the waste for drying prior to extraction of a larger RDF fraction. MBP aims at stabilizing the organic to minimize gas as well as leachate emissions in landfill while MBS maximizes the RDF and materials recovery. Within this general classification, multiple variations can be found and it can be stated that probably there are no two identical plants.

The proliferation of these facilities was particularly remarkable in Spain where the waste treatment capacity was increased by 5 million tonne by installation of 50 new MBT plants (MMA, 2006). Particularly, in the region of Castilla y León (Spain), where more than 1.2 million tonne of waste are generated annually, $11 \mathrm{MBT}$ plants have been built serving a population of 2.5 million of inhabitants within $94,223 \mathrm{~km}^{2}$. It should be noticed that selective source-segregation (separate collection of metals and plastic containers along with glass and paper) corresponds to only $12 \%$ (as for 2009) of the total collected waste (MMA, 2010), the remaining $88 \%$ being residual MSW. All the residual MSW generated in this region is sent to MBT prior to landfilling.

Over the last ten years these plants have been in service, no specific assessments on their environmental performances have been performed. To this respect life cycle assessment (LCA) is a useful tool allowing for a holistic and systematic assessment of both direct and indirect environmental impacts of a selected system. LCA includes impact categories ranging from climate change (greenhouse gas (GHG) emissions) to human health impacts associated with the release of toxic substances, and to environmental impacts caused by physical changes of the land. In the literature a few 
LCA studies specifically focusing on MBT plants exist: for example Abeliotis et al. (2012) assessed the environmental profile of a MBT plant located in Athens; a MBTP sited in Liossia (Greece) was included in the study of Papageorgiou et al. (2009); Bovea et al. (2010) considered this option as one of the MSW management scenarios in their Spanish case study and Juniper (2005) reviewed a number of MBT plants in Europe and reported associated environmental performances. In these studies, however, the input waste as well as the RDF composition was not experimentally determined and in the case of Juniper (2005) the focus was specifically on the UK waste management system. What was generally missing was an assessment taking into account plant-specific (and experimentally investigated) waste compositions as well as local conditions including actual plants efficiencies (i.e. materials and energy recovery) and type of marginal energy source replaced. These may significantly affect the LCA results as was reported by De Feo and Malvano (2009) when several waste management scenarios were analyzed and MBT plant was one of them.

Bearing in mind these grey areas of the research, the objective of the present is to provide an insight into the impacts that the current operation of these waste treatment plants has on the environment. LCA results can be used as technical support for decision-making processes since, frequently, appropriate modifications in the management strategy can induce significant environmental savings. Therefore, the aims of this study were: i) to assess the current environmental performance of eight selected MBT plants with different operational system and waste input in order to illustrate the processes contributing with significant environmental burdens or benefits; ii) to compare the environmental performances of the eight MBT plants provided they treated the same waste input and to illustrate the role played by the waste composition and the technical performance of the individual plants (i.e. disregarding the effects of the different waste compositions); iii) to highlight potential environmental improvements which could be induced by changes in the management system (including both the MBT technology and the associated downstream processes, e.g. RDF landfilling). 


\section{Methodology}

\subsection{The geographical region assessed: Castilla y León}

The region of Castilla y León (Spain) covers an area of 94,223 $\mathrm{km}^{2}$ and has a population of 2.5 million of inhabitants. More than 1.2 million tonne of waste are generated annually. In the last decade $11 \mathrm{MBT}$ plants have been built to treat source-segregated and residual MSW (the second being $88 \%$ of the generated as mentioned earlier). Eight out of these 11 plants were operating at full capacity when this research was conducted and, therefore, were included in this study representing at least $80 \%$ of the residual waste treatment capacity of the region. These plants can generally be classified as MBP: the organic fraction is biologically stabilized after recovery of recyclables and RDF. Two types of waste are received and independently treated in these facilities: i) a mix of plastic and metal containers collected in separate bins (i.e. derived from household source-segregation) are manually divided into a number of fractions such as ferrous metals, aluminium containers, beverage cartons, LDPE (low density polyethylene), HDPE (high density polyethylene) and PET (polyethylene terephthalate). ii) Residual waste from households, hereinafter called 'residual MSW' (rMSW), is screened in rotary sieves (trommels); the fine fraction from trommels mostly consists of organic matter and is sent either to anaerobic digestion or to composting; selected recyclable materials are recovered from the coarse fraction after separation of the organic. The remaining fraction (RDF), representing about $40 \%$ by weight of the input rMSW, is currently baled and sent to landfill. The focus of this study is on the treatment of the rMSW only.

\subsection{MBT plants in Castilla y León: general description}

In Castilla y León the rMSW is collected and transported by collection trucks to the local MBT plant. Here a first manual selection station removes bulky items to avoid possible subsequent blockages. The waste stream is then conveyed to the trommel where a size separation is performed. The coarse fraction is conveyed to the second manual selection station where recyclable materials such as beverage cartons, LDPE, 
HDPE and PET are separated and recovered. The residual (or RDF) is baled and sent to landfill after removal and recovery of ferrous and aluminium metals by magnets and eddy current systems (ECS). The fine fraction from the trommel (hereinafter named organic fraction of MSW, i.e. OFMSW) is conveyed to biological treatment after removal of ferrous and aluminium metals similarly to RDF. The biological treatment may be of two types: I) combined anaerobic digestion and post-composting and II) direct composting. Since the main difference among the plants is the biological treatment, the eight MBT plants under assessment can be classified according to two groups: i) MBT type I, where the OFMSW from the trommels is anaerobically digested (hydraulic retention time, i.e. HRT, of about 20 days) and the produced biogas combusted in gas motors to generate electricity and (in two cases) partly used for heating the process, and ii) MBT type II, where the OFMSW is composted in tunnels (about 20 days) and further sent to maturation windrows. In plants type $I$ the digestate is also further introduced into composting tunnels for about 15 days in order to stabilize the undegraded organic matter and to later dry the product in maturation windrows.

\subsection{Waste characterization}

Eight MBT plants operating at full-capacity were investigated for a period of two years. Several technical visits were conducted in different seasons, main technical features inspected and samples of inputs and outputs collected and analyzed. As a result, global material balances were developed for each individual MBT plant and recovery efficiencies, i.e. distribution of the selected waste material fractions among the output streams (i.e. transfer coefficients) were calculated.

The first step was to characterize the rMSW input to each plant so to define the eight individual waste compositions (in terms of waste material fractions). For each individual MBT plant, 16 samples (each of about $1000 \mathrm{~kg} \mathrm{rMSW}$ ) were taken from the reception ditch. The samples were divided into quarters and two opposite sectors were taken; the subsample was mixed and divided again into quarters, two of which selected to compose the final sample (ca. $250 \mathrm{~kg}$ ). This was manually sorted into 19 waste material fractions according to MODECOM procedure (ADEME, 1998) and weighted in situ. 
In order to define an overall mass balance for the MBT plants the RDF and the OFMSW were also characterized. The RDF composition was determined using the same approach as for the input rMSW (16 samples were collected; 19 waste material fractions were sorted and weighted from the final sample of $250 \mathrm{~kg}$ ). For the OFMSW, due to the smaller size, (smaller than $90 \mathrm{~cm}$ ), 16 samples of $50 \mathrm{~kg}$ were collected. Once all these streams were analyzed, the amount of recyclable materials recovered in the mechanical processes can be calculated by means of a global mass balance. Similarly, transfer coefficients (i.e. distribution of the waste material fractions among the output streams) for selected waste materials were calculated for each individual MBT plant.

\subsection{Functional unit definition}

The functional unit of the LCA was the treatment of 1 tonne of wet rMSW (i.e. residual MSW left-over after source-segregation at the household) with the purpose of stabilizing the organic matter in order to achieve a final stabilized compost material (BOE, 2005; Hogg et al., 2002). The geographical scope was Spain (Castilla y Leon). The temporal scope can be approximated with '2013-2015' as technologies efficiencies, waste composition and amount, transport distances and marginal energy sources ies refer to current knowledge and practices (in other words, no forecasting has been made). The environmental impacts were assessed for a time horizon of 100 years, from the moment when the rMSW was collected. The 'zero burden' approach was applied: all upstream emissions associated with generating the waste were omitted from the LCA. The chemical composition of each waste material fraction was assumed from Riber et al. (2009). The boundary of the system was set at the point of rMSW collection; further impacts and savings associated with downstream utilization of produced electricity (e.g. from biogas or RDF combustion) and landfilling of residuals (e.g. rejects, RDF, eventual incineration residuals, etc.) was accounted for by system expansion following the principles of consequential LCA (Finnveden et al., 2009; ISO 2006a, ISO 2006b). This implied that the products generated by the system (e.g. electricity and recycled materials) substituted the relative marginal products in the market. In the particular case of electricity, the marginal technology was assumed to be natural gas-fired power plants based on MITYC (2011) and IDAE (2010). These indicate a trend on increasing the 
energy provision by expanding the capacity of natural gas-based power production while keeping coal and fuel oil steady. This assumption is also in accordance with other recent LCA studies having Spain as geographical scope (e.g. Meneses et al., 2012). The influence of this choice was tested by assessing the LCA results also for the case of coal as marginal fuel-source for electricity production. For landfilling, the system was credited with the savings associated with carbon sequestration over the considered 100 years horizon.

\subsection{Impact assessment}

The assessment was carried out according to the LCA method EDIP 1997 (Wenzel et al., 1997). The assessment included several impact categories covering potential burdens to air, soil, surface and groundwater and potential hazards to humans. These categories were divided into three main groups: non-toxic environmental impact categories (global warming - GW, photochemical ozone formation - POF, stratospheric ozone depletion - SOD, acidification - AC and nutrient enrichment - NE) and toxic environmental impact categories (ecotoxicity in soil - ETs and in water (chronic) ETwc, human toxicity via soil - HTs, via water - HTw and via air - HTa). To these, another specific category (spoiled groundwater resources -SGR) was added in order to include in the assessment the potential impacts associated with contamination of groundwater. The SGR is calculated based on the amount of groundwater that may be contaminated from an input of leachate by diluting the leachate to the drinking water standards, as described by the guidelines provided by WHO (2006). This assumes that groundwater is used as drinking water resource in the region under assessment.

In the LCA-modelling it was assumed that emissions of biogenic carbon dioxide are neutral with respect to GW (i.e. global warming emission factor equals 0). With respect to landfilling, this dictates that biogenic carbon left in the landfill after the LCA time horizon considered (100 years) is considered as an avoided emission of carbon dioxide and therefore a negative contribution (i.e. a saving) was assigned (Christensen et al., 2009). 
The assessment was facilitated with the waste management-dedicated LCA software EASEWASTE (Kirkeby et al., 2006). The results were expressed as characterized values (e.g. $\mathrm{kg} \mathrm{CO}_{2}$-eq. tonne ${ }^{-1} \mathrm{ww}$ ).

\subsection{LCA scenarios}

For each type of MBT ( $I$ and $I I$ ), four corresponding waste management scenarios (based on the eight MBT plants investigated) were assessed: MBTP I-1, MBTP I-2, MBTP I-3 and MBTP I-4 corresponding to type I and MBTP II-1, MBTP II-2, MBTP II-3 and MBTP II-4 corresponding to type II. The LCA included two sets of scenarios: the first set (a) consisted of the selected eight waste management scenarios (i.e. MBTP I-1, MBTP I-2, MBTP I-3, MBTP I-4, MBTP II-1, MBTP II-2, MBTP II-3, MBTP II-4) where the waste composition was specific for each individual plant (as investigated). The second (b) consisted of the same eight waste management scenarios with the difference that the waste input to the individual MBT plants was the same (average waste composition for the region, see section 3). The latter allows for comparing the technical performance of the individual MBT plants (including further treatments) disregarding the effects of different waste compositions. The system boundary is exemplified in Figure 1 for the case of scenario MBTP I-3 (a). A total of 16 scenarios were therefore assessed: 8 (scenarios, i.e. I-1 to II-4) x 2 waste compositions (i.e. a and b) $=16$.

In addition, the potentials for optimizing the environmental performance of the assessed waste management scenarios were evaluated by analyzing the following changes in the management system: i) RDF incineration instead of landfilling. ii) Optimization of the biological treatment: this consisted on modelling the biological treatment in all the scenarios conformingly with the best performing digestion process (that is, MBTP I-2, see Table 1). iii) Optimization of materials recovery: the potentials for GHG savings associated with improved materials recovery at the MBT plants were quantified. It was assumed that the MBT plants were upgraded with additional installation of the following automatic selection units: optical separator for hard plastic (4.7 kWh tonne $\left.{ }^{-1} \mathrm{ww}\right)$, PET (1.5 kWh tonne $\left.\mathrm{kW}^{-1} \mathrm{ww}\right)$, soft plastic (assumed as for hard 
plastic), glass (glass breaker and optical glass sorting, $20 \mathrm{kWh}$ tonne $\mathrm{k}^{-1} \mathrm{Ww}$ ), aluminium (ECS, $0.88 \mathrm{kWh}$ tonne ${ }^{-1} \mathrm{ww}$ ) and ferrous metals (magnet, $2.4 \mathrm{kWh}$ tonne ${ }^{-1} \mathrm{ww}$ ). Data were based on Combs (2012). Paper and cardboard were included in the analysis (manual separation was assumed). However, improved recovery of these may be limited by the contamination with organic and the results have to be regarded only as upper potentials.

Notice that in the present study no sensitivity analysis-dedicated section is presented as the main scenario uncertainties associated with choices about type of marginal energy_source, carbon sequestration in landfills, variation of the waste composition and changes in the management systems were tested and integrated within the results section (3.1-3.3 and related Figures).

*Figure $1 *$

\subsection{Waste treatment technologies}

\subsubsection{MBT plants}

Each individual MBT plant was modelled as a combination of mechanical separation and biological treatment. The recovery efficiencies of the selected waste material fractions were calculated based on the experimental data. The consumption of energy of each machine and operation occurring at the plant under assessment was based on Combs (2012). The average electricity consumption of the assessed plants for the mechanical and manual operations was estimated to $15 \mathrm{kWh}$ tonne $\mathrm{f}^{-1} \mathrm{ww}$. The biological treatments for both types of MBT plants were modelled according to Boldrin et al. (2011) with respect to $\mathrm{N}_{2} \mathrm{O}, \mathrm{CH}_{4}$ and $\mathrm{NH}_{3}$ emissions. The purpose of the biological treatment is the stabilization (aerobic or anaerobic or in combination) of the degradable organic matter in order to achieve a final composted material having low methane potential (typically $<20 \mathrm{Nm}^{3}$ tonne $^{-1} \mathrm{ww}$ ) which allows sustainable landfilling with decreased environmental impacts especially with respect to gas and leachate generation (Stegmann, 2010; Cossu et al., 2003). The residual methane potential of the stabilized organic matter was assumed $15 \mathrm{Nm}^{3}$ tonne ${ }^{-1} \mathrm{wW}$ according to previous studies 
(Manfredi et al., 2010a). The corresponding $\mathrm{CH}_{4}$ emissions occurring in the landfill were accounted for in the LCA.

\section{MBT type I}

Biological treatment in MBT type $I$ was modelled as a combination of anaerobic digestion and post-composting. The OFMSW screened from the trommels, after a pretreatment based on water addition, was fed to the anaerobic reactor in a continuous flow process. The biogas net electricity production was based on specific data from the plants operators (Table 1). The methane content in the biogas was $65 \%$ per volume. The fugitive methane emissions from the reactor were set to $1 \%$ of the produced $\mathrm{CH}_{4}$ based on recent LCA studies (Böriesson and Berglund, 2006; Jungbluth et al., 2007; Hamelin et al., 2011.). Unburned methane in the gas engine was assumed $434 \mathrm{~g} \mathrm{CH}_{4} / \mathrm{MJ}$ combusted based on Nielsen et al. (2010). After ca. 20 days, the digestate was sent to post-composting. The post-composting phase consisted of about 20 days in composting tunnels (see section MBT type II) followed by a maturation period of about 2 months in order to achieve a final stabilized quality. The carbon degradation during postcomposting was estimated based on mass balances (see supporting information, SI). Emissions of $\mathrm{CH}_{4}, \mathrm{~N}_{2} \mathrm{O}$ and $\mathrm{NH}_{3}$ were considered the main products of degradation (see section MBT type II). According to current practices, the final product (compost, currently used as daily cover in the adjacent landfills) was landfilled despite the refinement was carried out. Similarly, the reject of this refining process was also landfilled.

*Table $1 *$

\section{MBT type II}

Biological treatment in MBT type II was modelled as composting tunnels based on a full-scale operating plant located in Italy (Boldrin et al., 2011). The degradation of each material fraction was modelled as a percentage of the VS content in the incoming waste; 
this corresponded to about $70 \%$ VS degradation for organic waste such as animal and vegetable food waste, $60 \%$ for yard waste, $10-20 \%$ for paper and cardboard fractions and $5 \%$ for beverage cartons and textiles. OFMSW and electricity consumption (about 20-25 $\mathrm{kWh}$ tonne $\mathrm{e}^{-1} \mathrm{wW}$ depending on the plant) were the main inputs to the composting process whereas compost, rejects from refining processes and emissions of $\mathrm{CH}_{4}, \mathrm{~N}_{2} \mathrm{O}$ and $\mathrm{NH}_{3}$ were the main outputs. According to Boldrin et al. (2011), the fugitive $\mathrm{CH}_{4}$ emissions were set to $0.2 \%$ of the degraded carbon, $\mathrm{N}_{2} \mathrm{O}$ emissions to $1.4 \%$ of the degraded nitrogen. About $98.5 \%$ of the degraded nitrogen was in the form of $\mathrm{NH}_{3}$ of which 99\% was assumed oxidized in biofilters (Boldrin et al. 2011) which are the current air treatment system at the assessed plants. The compost and the rejects were assumed landfilled according to current practices.

\subsubsection{Associated waste treatment technologies}

The remaining waste treatment technologies associated to the MBT plants (collection and transport, landfilling, recycling and incineration) are thoroughly detailed in the supporting information (SI).

\section{Results and discussion}

The composition of the rMSW as well as RDF of the individual MBT plants is shown in Table 2 along with the average rMSW composition for the region. This included two additional MBT plants located in Castilla y León (which are not addressed in this study). The recovery efficiencies (i.e. percent of each individual waste material recovered) calculated for each individual MBT plant is detailed in Table 3.

On a wet basis, the rMSW was composed by about $50 \%$ organic matter, $14 \%$ paper and cardboard and $11 \%$ plastics. Based on trommel separation, the recovery efficiencies for organic matter (i.e. share sent to biological treatment) were above $80 \%$ for all plants. However, these 'organic' streams contained high percentages of improper materials as highlighted in previous studies (Montejo et al., 2010). Paper, cardboard, glass, beverage cartons and the different types of plastic are recovered manually in these MBT plants hence recovery efficiencies varied widely. Ferrous and aluminium metals were mechanically separated, therefore the relative recovery efficiencies were generally 
higher compared with the remaining waste materials. The residual (named RDF) was mainly composed of organic matter (about 25\%), paper and cardboard (about 30\%) and plastic (about 25\%). This fraction is currently landfilled (Montejo et al., 2011) despite its high calorific value (up to $18 \mathrm{MJ} \mathrm{kg}^{-1} \mathrm{ww}$ ). For the scenarios under assessment a biogenic carbon balance is also reported (Table S1).

\section{*Table 2* \\ *Table $3 *$}

The LCA results for the eight scenarios are shown in Figure 2-3. These included the a) 'waste-specific' results (i.e. environmental impacts associated with the individual scenarios provided the waste input is specific for each individual MBT plant) and b) 'waste-average' results (where the waste input is the average for 'Castilla y León' for all the scenarios). The latter allows for comparing the technical performance of the individual MBT plants disregarding the effects associated with differences in the waste compositions. The impacts of the principal processes involved have been detailed in the charts. The processes were grouped into: i) Transportation (waste collection and transport of recovered materials and rejects), ii) Mechanical treatment (mechanical material recovery), iii) Biological processes (composting or combined process with anaerobic digestion and post-composting), iv) Recycling (facilities where recovered materials are reprocessed) and v) Landfilling (of all the compost, rejects and RDF generated). Impacts/savings for the individual waste management scenarios were obtained by subtracting the avoided impacts (negative values in the figures) from the induced impacts (positive values). Any net value below the zero axes thus indicates an environmental improvement as compared with the fossil fuel reference (in which electricity is provided by natural gas and materials are produced from virgin resources; no environmental burden is assumed embedded in the waste input). In addition, the overall LCA results in the case of coal being the marginal source for electricity production are also displayed ('cross indicator'). Notice that the discussion in section 3.1-3.3 (e.g. numerical LCA results reported) focuses on the case where natural gas is 
the marginal energy source, unless otherwise specified. Normalized LCA results were also calculated and can be found in the SI.

\section{*Figure $2 *$ \\ *Figure $3 *$}

\section{1 'Waste-specific' results (current performance)}

\subsubsection{Non-toxic impact categories}

On GW all the scenarios contributed with environmental savings. This was expected as a zero-burden approach is assumed. However, the magnitude of the savings varied depending on the scenario (which relates to the type of MBT plant, i.e. $I$ or $I I$ ) and on the type of marginal energy source considered, that is, natural gas or coal. The choice of natural gas determines that the energy recovery processes are less beneficial on GW compared with choosing coal. This is also expected as coal has a significantly higher GHG emission factor than natural gas (in this study: 1.1 vs. $0.49 \mathrm{~kg} \mathrm{CO}_{2}$-eq. $\mathrm{kWh}^{-1}$ ). This finally implicates that, when natural gas is the marginal energy source, most GHG savings are provided by other processes than energy recovery's, for example recycling or carbon sequestration in the landfill. The overall GW savings ranged from -340 for MBTP II-1 (type II) to $-120 \mathrm{~kg} \mathrm{CO}_{2}$-eq. tonne ${ }^{-1}$ ww for MBTP II-2 (type II). There was no clear evidence that scenarios with type $I$ were better than $I I$ or vice versa. In fact, as opposed to previous studies on similar subjects (e.g. Manfredi et al., 2011; Boldrin et al., 2011) where anaerobic digestion of the organic matter was concluded to be favourable over direct composting, in the present this was not the case. The primary reason for this was the wide variation of energy and materials recovery efficiencies across the eight scenarios. For example, MBTP I-1 and MBTP I-2 had high electricity recovery but scarce materials recovery efficiencies. In addition, methane production was lower than in the other MBT type II. Second, in the aforementioned studies coal was generally assumed as marginal energy_source; this determined significantly higher benefits associated with the energy recovery processes.

For all the scenarios the environmental savings were primarily associated with (Figure 2a): (1) recycling, (2) landfilling (carbon sequestration) and (3) biological 
processes (substitution of fossil fuel through energy produced during anaerobic digestion). (1) Recycling determined significant savings in all scenarios; these were largely dependent on the total amount of recovered materials (i.e. product of plant separation efficiency and input material amount) particularly with respect to i) paper, ii) plastic and iii) metals. The greatest savings were found for MBTP II-1, MBTP II-2 and MBTP II-4 (-250, -240 and $-230 \mathrm{~kg} \mathrm{CO}_{2}$-eq. tonne ${ }^{-1} \mathrm{ww}$, respectively) which also showed the highest recovery efficiencies for these recyclables (Table 3). These results are in agreement with previous studies focused on recycling of different materials (Damgaard et al., 2009; Manfredi et al., 2011; Merrild et al., 2009; Merrild et al., 2012; Tonini and Astrupet at. (2012a)). (2) Landfilling of compost (that is, stabilized organic) and RDF resulted in significant GW benefits for all the scenarios (ranging between -200 (MBTP II-4) and -140 (MBTP I-4) $\mathrm{kg} \mathrm{CO}_{2}$-eq. tonne ${ }^{-1} \mathrm{ww}$ ); these savings were completely associated with carbon sequestration whereas minor impacts (about 15-25 $\mathrm{kg} \mathrm{CO}_{2}$-eq. tonne $\left.{ }^{-1} \mathrm{ww}\right)$ were a consequence of residual methane emissions and energy consumption for the operations. Between $84 \%$ and $91 \%$ of the total biogenic carbon sequestered was associated with the RDF and between $9 \%$ and $16 \%$ with compost and rejects from the biological treatment (see Table S1). These results are in agreement with the findings of previous studies (e.g. Manfredi et al., 2009, Manfredi et al., 2010b, and Manfredi et al., 2011) where potential savings associated with carbon sequestration were illustrated for different waste types. (3) Biological processes resulted in GW savings only for MBTP I-2 when natural gas was the marginal energy source thanks to the significant electricity recovery. When coal was the marginal energy source also MBTP I-1 achieved net GHG savings. For all the scenarios, the GHG emissions $\left(\mathrm{CO}_{2}-\right.$ eq. tonne $\mathrm{e}^{-1} \mathrm{ww}$ ) ranged from -7 to 48 in the case of natural gas and -48 to $75 \mathrm{~kg}$ in the case of coal. As shown by the results for MBTP I-3 and MBTP I-4, a gross electricity efficiency of $13-14 \%$ was not sufficient to assure 'GHG-neutrality' to the biological treatment itself (i.e. to compensate the impacts due to the emissions and consumptions) neither in the case of natural gas nor coal as marginal energiesenergy sources. However, an optimized use of the biogas-energy through, for example, maximization of the electricity production and later use of the waste heat from the gas engine to heat the digestion process may drastically increase the associated GHG savings. Additional 
environmental impacts were caused by mechanical treatment to separate organic matter and recyclables (ca. $8.5 \mathrm{~kg} \mathrm{CO}_{2}$-eq. tonne ${ }^{-1} \mathrm{ww}$ due to energy consumption) and transportation (between 17 and $40 \mathrm{~kg} \mathrm{CO}_{2}$-eq. tonne ${ }^{-1}$ ww depending on the amount of recyclables transported).

The results for $\mathrm{AC}$ and $\mathrm{NE}$ followed a similar trend among the assessed scenarios. On both categories recycling was the most important contributor to the savings. All the other processes determined environmental impacts, primarily related to (the order reflecting the relevance): $\mathrm{NH}_{3}$ emissions from composting (biological processes), $\mathrm{NH}_{3}$ and $\mathrm{PO}_{4}{ }^{3-}$ from landfilling (leachate) and $\mathrm{NO}_{\mathrm{x}}$ (transportation). On $\mathrm{NE}$ $\mathrm{NO}_{\mathrm{x}}$ and $\mathrm{NH}_{3}$ emissions exceeded the avoided $\mathrm{N}$-emissions associated with recycling determining an overall impact on this category in all the addressed scenarios. This was not the case for AC where only one scenario performed with a net impact (MBTP II-2) due to scarce materials recovery efficiencies at the MBT. This could be avoided by, for example, optimizing metals (particularly aluminium) recovery.

Regarding the remaining non-toxic categories, no remarkable differences among the scenarios were found in the categories SOD and SGR (Table S3). Here the impact was totally caused by landfilling (due to CFCs and ammonia emissions to groundwater through leachate). On POF impacts were primarily caused by transportation (VOCs) and to a minor extent by landfilling and biological processes (fugitive $\mathrm{CH}_{4}$ emissions).

\subsubsection{Toxic impact categories}

As illustrated in Figure 3a, the results on the toxic categories ETwc, HTw and HTs highlighted the benefits associated with recycling to which all the environmental savings were connected across the different scenarios. As a consequence, the scenarios with highly efficient recovery of recyclables at the MBT plant achieved the greatest performances. Particularly, the recovery efficiency of aluminium determined the performances on ETwc, HTs and, to a minor extent, also on HTw: the higher the overall recovery at the MBT (see Table 3) the better the results; the impacts were mostly due to transportation and landfilling as a consequence of metals emissions (through leachate) and uncombusted hydrocarbons (transportation). On ETwc only the scenarios with aluminium recovery efficiency at the MBT above $60 \%$ achieved environmental savings 
(that is, MBTP I-1, MBTP I-2, MBTP I-4 and MBTP II-4); the impacts from transport and landfilling were comparable for all scenarios. On HTw the performance was mainly related to energy and aluminium recovery (and consequent avoided emissions from fossil fuel combustion and virgin material production): the scenarios with direct composting and scarce recovery efficiencies (that is, MBTP II-2, MBTP II-3 and MBTP I-4) performed therefore worst. All the assessed scenarios performed with impacts on HTa (Table S3); this was principally attributed to VOCs emissions from transportation. The impacts on ETs (not shown) were negligible compared with the remaining categories.

\section{2 'Waste-average' results (current performance)}

Figure $2 b-3 b$ allows for comparing the scenarios disregarding the effects associated with the differences in the waste composition thus gaining insight into the technical performances of the MBT plants investigated. The results for GW highlighted that, generally, the performance of the scenarios with MBT type I was better than type II provided high electricity recovery (e.g. MBTP I-1 and MBTP I-2). It should be noted how the overall magnitude of the GW performance was affected by the changes in the waste composition. The paramount average variation of GHG savings between case a and $b$ (i.e. absolute average GHG variation of the eight scenarios) corresponded to about $22 \%$. The largest variation was seen for MBTP II-2 (40\% net increase of GHG savings) as a consequence of the increased content of ferrous metals, paper and cardboard in the input waste composition.

The results for $\mathrm{AC}$ and $\mathrm{NE}$ reflected the overall materials recovery (and consequent recycling) efficiency: MBTP II-4 performed best thanks to higher recovery for aluminium, plastic, cartons and paper compared with the remaining scenarios. However, as opposed to $\mathrm{AC}$, on $\mathrm{NE}$ all the scenarios contributed with environmental impacts as a consequence of higher $\mathrm{N}$-emissions from composting and landfills in comparison with the avoided $\mathrm{N}$-emissions connected to recycling. Yet, efficient material recovery at MBT has the potential to mitigate the overall NE impact (e.g. see MBTP II4). The impacts on the remaining non-toxic categories (POF, SOD and SGR) were 
primarily due to landfilling and transportation as earlier described; the magnitude was comparable for all the scenarios (Table S3).

On ETwc and HTs the results were mainly affected by the amount of recovered aluminium (which determines the most significant savings on these categories as earlier described): the scenarios having the lowest recovery efficiency at the MBT (MBTP I-3, MBTP II-1 and MBTP II-2, see Table 3) were the worst. It can be noticed that the overall performance of MBTP I-1 and MBTP II-4 decreased in (b) compared with (a) as a result of the diminished share of aluminium in the average 'Castilla y León' waste composition compared with the specific waste input to these plants (Table 2). In HTw the major savings were associated with recycling of paper and aluminium and also, to a minor extent (when natural gas is the marginal enesource) energy recovery, as earlier described. The combination of no-energy as well as low materials recovery determined net impacts in the case of MBTP II-2. This also applied to MBTP I-4 and to all scenarios with MBT type II when coal was the marginal energy_source. All the addressed scenarios contributed with comparable impacts (see Table S3) on HTa; these were primarily attributed to transportation as earlier described.

\subsection{Potentials for optimizing the environmental performance}

Figure 4-5 shows the environmental consequences in terms of benefits and/or impacts associated with potentially improved waste management scenarios (i, ii and iii). The bars in Figure 4 indicate the net difference in the environmental impact or saving between the improved and the baseline scenario that is set to zero and used as reference (i.e. $\Delta$ saving or $\Delta$ impact $=$ improved value - baseline value): a bar pointing towards negative values indicates that the improved scenario achieved increased environmental savings compared with the baseline (and viceversa). The waste-specific scenarios were used as baseline. Figure 4(i) shows the variation in the environmental performance in the case that RDF was incinerated instead of landfilled. Figure 4(ii) shows the variation when the organic matter is anaerobically digested with optimized energy recovery (see section 2.6) instead of 'directly' composted.

Figure 5 shows the paramount average GHG emissions (i.e. average of the eight scenarios) associated with $100 \%$ material recovery at the MBT or, alternatively, $100 \%$ 
material incineration, relative to the baseline LCA results. These were set to zero and used as reference. Thus, any value below zero represents a saving compared with the baseline (and viceversa). Table S4 reports the detailed results for the individual scenarios. This analysis was performed to illustrate the potentials for GHG savings associated with the management of the individual waste materials.

The results (Figure 4-5) showed that from a GHG perspective significant environmental improvements may be achieved by a combination of the following (the order reflecting the relevance): 1) increased materials recovery (primarily metals and plastic) and 2) optimized biological treatment of OFMSW. Incineration of RDF (instead of landfilling) was beneficial only if coal was the marginal energy_source. These results are in agreement with Arena et al. (2003) where one MBT plant was considered as one of the waste management scenarios. Overall, optimization of metals and plastic recovery should be prioritized. This would enhance the environmental performance on all environmental categories (exemplified in Figure 5 for GW). The associated savings varied across the scenarios depending upon the waste composition. In the case of paper and cardboard, additional savings from improved recovery are dramatically dependent upon the assumptions regarding $\mathrm{C}$ sequestration and therefore the considered time horizon. If $\mathrm{C}$ sequestered was not accounted, the additional savings from paper recycling compared with landfilling would be much more significant (Figure 5 and Table S4).

Optimization of the biological treatment also induced additional GW savings (between -8 and $-93 \mathrm{~kg} \mathrm{CO}$-eq. tonne ${ }^{-1} \mathrm{ww}$ ). Note that biogas may also provide additional benefits in relation to storability and flexibility of use in the perspective of future energy systems with increased penetration of wind and other fluctuating renewables such as photovoltaic and tides (among the others: Lund, 2007; Mathiesen et al., 2011a; Mathiesen et al., 2011b; Tonini and Astrup, 2012b).

As aforementioned RDF incineration decreased the GW performances compared with landfilling when $\mathrm{C}$ sequestration was accounted for along with natural gas as marginal energy source. The reason for this was that the $\mathrm{CO}_{2}$ savings from avoided natural gas combustion were largely compensated by waste-specific $\mathrm{CO}_{2}$ emissions (from plastic). As opposite to this, the GHG performance was instead improved 
compared with the baseline (landfilling) when coal was the marginal energy source (Figure 4). This indicates that RDF should be used to substitute for fossil fuels with higher emission factor than that of coal (see also 3.3.1). Additionally, RDF incineration strongly mitigated the impact potential on all the remaining categories, particularly on SGR. The latter was on average reduced down to ca. $1 / 3$ of the current impact potential.

\section{*Figure 4* \\ *Figure 5*}

3.3.1 Energy from RDF: effects of energy efficiency, plastic recovery and fuel substituted on $G W$

As aforementioned RDF incineration resulted in worse GHG performance compared with the baseline (landfilling) when natural gas was the marginal energy source. This may change if: 1) the electricity efficiency of the combustion process increases, 2) sorting and recovery of plastic at the MBT is applied prior to RDF incineration, and 3) the substituted fuel has higher $\mathrm{CO}_{2}$ emission factor than that of natural gas. The first (1) was assessed by identifying the net electricity efficiency $\left(\eta_{\text {power plant }}\right)$ that should be achieved at the dedicated RDF incinerator (or a generic power plant) in order to equal the same GHG savings of the baseline (where plastic along with the remaining RDF is landfilled and carbon from paper and organic is sequestered). The calculation was performed according to Equation S1 (SI). Similarly, for the second (2), the plastic recovery efficiency $\left(\eta_{\text {rec }}\right)$ that should be achieved at the individual MBT plants to equal the GHG performance of the baseline was evaluated. The calculation was performed according to Equation S2 (SI). The third (3) was earlier exemplified in the case of coal as marginal energy source (section 3.3). However, Equation S3 (SI) allows recalculating the specific $\mathrm{CO}_{2}$ emission factor that the 'substituted fuel' $\left(\mathrm{EF}_{\text {fuel }}\right)$ should assume in the individual MBT scenarios to equal the GHG performance of the baseline. As reported in Table S5, a net electricity efficiency of $49-53 \%$ should be achieved to equal the GHG performance of the baseline. Alternatively, recovery efficiency at the MBTs greater than $85-100 \%$ should be achieved for the considered recyclable plastic fractions (see SI). The $\mathrm{CO}_{2}$ emission factor of the 'fuel substituted' varied between 67 and $72 \mathrm{~kg} \mathrm{CO}$-eq. $\mathrm{MJ}^{-1}$ 
depending on the scenario (Table S5). Thus, the substitution of any fuel having emission factor above this range would induce net GHG savings compared with the baseline (RDF landfilling). This might be the case, for example, of substitution of light oil, heavy fuel oil or coal (emission factors greater than $80 \mathrm{~kg} \mathrm{CO}_{2}$-eq. $\mathrm{MJ}^{-1}$ ).

\subsection{Perspectives}

The results of this research suggest that the assessed MBT plants, even if recently commissioned, aim at a safe disposal (e.g. stabilization of the OFMSW prior to landfilling) rather than at maximizing energy and materials recovery. In this perspective, large potentials exist to optimize the environmental performance, thereby changing the perception on MSW from 'waste to be disposed' to 'resource and energy carrier'. Table S6 presents an overview of the total annual GHG savings that could be achieved in each individual MBT plant by optimizing biogas-energy and materials recovery (RDF is assumed landfilled). A total was also estimated. Overall, the estimated potential for GHG emission savings equalled ca. 180,000-190,000 tonne $\mathrm{CO}_{2}$-eq. $\mathrm{y}^{1}$ depending on the assumption for the marginal electricity source.

The fact that the biggest savings are associated with recovery/recycling along with the scarce GHG performance of RDF incineration (under the assumptions made about marginal electricity source and carbon sequestration) highlight that optimization of materials recovery is crucial, if the focus is mitigating GHG emissions. Future studies should thus focus on evaluating alternative options to maximize recycling: these should include source-segregation strategies to be integrated with optimized mechanicalbiological treatment. In addition, optimal strategies for energy recovery from RDF should also be further evaluated, likely including heat recovery (for example for industry or for district heating/cooling), co-firing in dedicated large scale power plants or in cement kilns, to maximize the total energy recovery.

\section{Conclusion}

From a GHG perspective the results documented that the environmental performance of the current waste management is primarily connected with material recovery, carbon sequestration in landfill and energy recovery through anaerobic digestion of the organic 
matter. The waste composition principally affected the magnitude of the benefits associated with recycling. These varied widely across the assessed scenarios depending on both waste composition and recovery efficiencies at the MBT. On the remaining environmental categories the performance was primarily dictated by the amount of recovered materials.

Overall, MBT plants with efficient energy recovery from the biogas performed better. High recovery efficiency for paper, plastic and metals determined significant environmental savings on the non-toxic categories whereas high recovery efficiency for aluminium induced considerable benefits on the toxic.

The recommendation for upgrading and/or commissioning of future plants is therefore to optimize materials recovery through increased automation of the selection and to prioritize biogas-electricity production from the OFMSW (with further re-use of the waste heat within the digestion process) over direct composting. The optimal strategy for RDF management depends upon the environmental compartment to be prioritized and the type of marginal energy source in the system. To this respect, further investigations are needed.

\section{Supporting information}

Additional information on: life cycle inventory of waste treatment technologies, carbon balance and LCA results is available free of charge via the Internet at http://www.sciencedirect.com.

\section{Acknowledgements}

The authors gratefully acknowledge the financial support from the Junta de Castilla y León (Spain). 


\section{References}

Abeliotis, K., Kalogeropoulos, A., Lasaridi, K., 2012. Life Cycle Assessment of the MBT plant in Ano Liossia, Athens, Greece. Waste Manage. 32, 213-219.

ADEME, 1998. Agence de l'Environnement et de la Maîtrise de l'Energie. MODECOM TM: Method for characterization of domestic waste. ADEME. Paris, pp. 61.

Arena, U., Mastellone, M.L., Perugini, F., 2003. The environmental performance of alternative solid waste management options: a life cycle assessment study. Chem. Eng. J. 96, 207-222.

Bilitewski, B., Oros, C., Christensen T.H., 2011. Mechanical Biological Treatment, in Christensen T.H. (Ed), Solid Waste Technology and Management. Willey \& Sons, London.

BOE, 2005. RD 824/2005 on fertilizer products. Boletín Oficial del Estado de 19 de julio de 2005, 171, 25592-25669. Available on web: <www.boe.es/boe/dias/2005/07/19/pdfs/A25592-25669.pdf>

Boldrin, A., Neidel, T.L., Damgaard, A., Bhander, G.S., Møller, J., and Christensen, T.H., 2011. Modelling of environmental impacts form biological treatment of organic municipal waste in EASEWASTE. Waste Manage. 31, 619-630.

Börjesson, P., and-Berglund, M., 2006. Environmental systems analysis of biogas systems - Part I: Fuel-cycle emissions. Biomass Bioenerg. 30, 469-485.

Bovea, M.D., Ibáñez-Forés, V., Gallardo, A., Colomer-Mendoza, F.J., 2010. Environmental assessment of alternative municipal solid waste management strategies. A Spanish case study. Waste Manage. 30, 2383-2395.

CEC, 1999. Council Directive 1999/31/EC on the landfill of waste. Official Journal of the European Communities L 182/1. Available at: http://www.central2013.eu/fileadmin/user_upload/Downloads/Document_Centre/OP_R esources/Landfill_Directive_1999_31_EC.pdf (accessed 12.12).

Christensen, T.H., Gentil, E., Boldrin, A., Larsen, A.W., Weidema, B.P., Hauschild, M., 2009. C balance, carbon dioxide emissions and global warming potentials in LCAmodelling of waste management systems. Waste Manage. Res. 27, 696-706.

Combs, A.R., 2012. Life Cycle Analysis of Recycling Facilities in a Carbon Constrained World. MS thesis, NC State Dept of Civil, Construction, and Environmental Engineering, North Carolina, USA. 
Cossu, R., Raga, R., Rossetti, D., 2003. The PAF model: an integrated approach for landfill sustainability. Waste Manage. 23, 37-44.

| Damgaard, A., Larsen, A.W., Christensen, T.H., 2009. Recycling of metals: accounting of greenhouse gases and global warming contributions. Waste Manage. Res. 27, 773780 .

De Feo, G., Malvano, C., 2009. The use of LCA in selecting the best MSW Formatted: English (U.S.) management system. Waste Manage. 29, 1901-1915.

ECN, 2009. Personal Communication with Josef Barth, Managing Director, European Compost Network (ECN).

Finnveden, G., Hauschild, M.Z., Ekvall, T., Guine, J., Heijungs, R., Hellweg, S., Koehler,_A., Pennington, D., Suh, S., 2009. Recent developments in Life Cycle Assessment. J. Environ. Manage. 91, 1-21.

Hamelin, L., Wesnaes, M., Wenzel, H., Petersen, B.M., (2011). Environmental Consequences of Future Biogas Technologies Based on Separated Slurry. Environ. Sci. Technol. 45, 5869-5877.

Hogg, D., Barth, J., Favoino, E., Centemero, M., Caimi, V., Amlinger, F., Devliegher, W., Brinton, W., Antler, S., 2002. Comparison of compost standards within the EU, Northamerica and Australasia" Main report. The Waste and Resources Action Programme. Available at: http://www.compostingvermont.org/pdf/WRAP_Comparison_of_Compost_Standards_ 2002.pdf (accessed 12.12).

IDAE $_{2}$ (2010). Spain's national renewable energy action plan 2011-2020. Available at: http://pvtrin.eu/assets/media/PDF/EU_POLICIES/National\%20Renewable\%20Energy $\% 20$ Action\%20Plan/202.pdf or

at http://ec.europa.eu/energy/renewables/action_plan_en.htm (accessed 12.12).

ISO, 2006a. Environmental Management-Life Cycle Assessment-Principles and Framework. 2nd ed. 2006; ISO 14040.

ISO, -2006b. Environmental Management-Life Cycle Assessment-Requirements and Guidelines. 1st ed. 2006; ISO 14040.

Jungbluth, N., Chudacoff, M., Dauriat, A., Dinkel, F., Doka, G., Faist, E.M., | Gnansounou, E., Kljun, N., Schleiss, K., Spielmann, M., Stettler, C., Sutter, J., 2007. Life Cycle Inventories of Bioenergy. Uster (Switzerland): Swiss Centre for Life Cycle Inventories, ESU-services, Ecoinvent report No 17. 
Juniper Consultancy Services Ltd., 2005. MBT: a Guide for Decision Makers: Processes-Policies-Markets. Available at: http://www.wmaa.asn.au/eventdocuments/2012skm/awt/or/Summary-Report.pdf (accessed 12.12).

Kirkeby, J.T., Hansen, T.L., Birgisdóttir, H., Bhander, G.S., Hauschild, M.Z., Christensen, T.H., 2006. Environmental assessment of solid waste systems and technologies: EASEWASTE. Waste Manage. Res. 24, 3-15.

Lund H., 2007. Renewable energy strategies for sustainable development. Energy 32, 912-919.

Manfredi, S., Christensen, T.H., Scharff, H., 2009. Landfilling of waste: accounting of greenhouse gases and global warming contributions. Waste Manage. Res. 27, 825-836.

Manfredi, S., Christensen, T.H., Scharff, H., Joeri, J., 2010a. Environmental assessment of low-organic waste landfill scenarios by means of life-cycle assessment modelling (EASEWASTE). Waste Manage. Res. 28(2), 130-140.

Manfredi, S., Tonini, D., Christensen, T.H., 2010b. Contribution of individual waste fractions to the environmental impacts from landfilling of municipal solid waste. Waste Manage. 30, 433-440.

Manfredi, S., Tonini, D., Christensen, T.H., 2011. Environmental assessment of different management options for individual waste fractions by means of life-cycle assessment modelling. Resour. Conserv. Recycl. 55, 995-1004.

Mathiesen, B.V., Lund, H., Hvelplund, F.K., Connolly, D., Bentsen, N.S., Tonini, D., Hansen, K., 2011a. CEESA 100\% Renewable Energy Scenarios towards 2050. Aalborg (Denmark): Aalborg University.;2011a. http://www.ceesa.plan.aau.dk (accessed 12.12).

Mathiesen, B.V., Lund, H., Karlsson, K., 2011b. 100\% Renewable energy systems, climate mitigation and economic growth. Appl. Energy 88, 488-501.

Meneses, M., Pasqualino, J., Castells, F., 2012. Environmental assessment of the milk life cycle: The effect of packaging selection and the variability of milk production data. J. Environ. Manage. 107, 76-83.

Merrild, H., Damgaard, A., Christensen, T.H., 2009. Recycling of paper: accounting of greenhouse gases and global warming contributions. Waste Manage. Res. 27, 746-753.

Merrild, H., Larsen, A.W., Christensen, T.H., 2012. Assessing recycling versus incineration of key materials in municipal waste: The importance of efficient energy recovery and transport distances. Waste Manage. 32, 1009-1018. 
MITYC, 2011. Ministerio de Industria, Turismo y Comercio. La energía en España 2010. Secretaría General Técnica, Madrid. Available at http://www.minetur.gob.es/energia/balances/balances/librosenergia/energia_espana_201 2_2ed.pdf (accessed 12.12).

MMA, 2006. Medio Ambiente en España 2005. Ministerio de Medio Ambiente. Centro de publicaciones, Secretaria General Técnica. Avalaible at: http://www.marm.es/es/estadistica/temas/estadisticas-ambientales/index2010-1029_23.19.09.1624.aspx (accessed 12.12).

MMA, 2010. Ministerio de Medio Ambiente. Perfil ambiental de España 2010. Centro de publicaciones. Secretaría Técnica. Available at: http://www.magrama.gob.es/es/ministerio/servicios/publicaciones/D_Gesti\%C3\%B3n_r esiduos_tcm7-164926.pdf (accessed 12.12)

Montejo, C., Costa, C., Ramos, P, Márquez, M.C., 2010. Analysis of the presence of improper materials in the composting process performed in ten MBT plants. Bioresour. Technol. 101, 8267-8272.

Montejo, C., Costa, C., Ramos, P, Márquez, M.C., 2011. Analysis and comparison of municipal solid waste and reject fraction as fuels for incineration plants. Appl. Therm. Eng. 31, 2135-2140.

Nielsen, M., Nielsen, O., Thomsen, M., 2010. Emissions from decentralised CHP plants 2007. Environmental project no. 07/1882. Project report 5 - Emission factors and emission inventory for decentralised CHP production. National Environmental Research Institute, Aarhus University. Available at: http://www.dmu.dk/Pub/FR786.pdf (accessed 12.12).

Papageorgiou, A., Karagiannidis, A., Barton, J.R., Kalogirou, E., 2009. Municipal solid waste management scenarios for Attica and their greenhouse gas emission impact. Waste Manag. Res. 27, 928-937.

Riber, C., Petersen, C., Christensen, T.H., 2009. Chemical composition of material fractions in Danish household waste. Waste Manage. 29, 1251-1257.

Stegmann, R., 2010. Landfilling: MBP Waste Landfills, in Christensen T.H. (Ed) Solid Waste Technology \& Management. John Wiley \& Sons, Ltd, pp. 788-799.

Tonini, D., Astrup, T., 2012a. Life-cycle assessment of a waste refinery process for enzymatic treatment of municipal solid waste. Waste Manage. 2012, 32, 165-76.

Tonini, D., Astrup, T., 2012b. Life-cycle assessment of biomass-based energy systems: a case study for Denmark. Appl. Energy 99, 234-246. 
Wenzel, H., Hauschild, M.Z., Alting, L., 1997. Environmental Assessment of Products. Methodology, tools and case studies in product development. Vol 1. Chapman \& Hall, London, England.

World Health Organization, WHO, 2006. Guidelines for Drinking-water Quality - First addendum to third edition. Volume 1. ISBN 924154696 4. WHO Press, 20 Avenue Appia, 1211 Geneva 27, Switzerland.

\section{Figures captions}

Figure 1. Illustration of the LCA system boundary for the case of MBTP I-3 (a) (MBT type I). rMSW: Residual municipal solid waste. MBTP: Mechanical-biological treatment plant. OFMSW: organic fraction of MSW (i.e. fine fraction screened by trommels). RDF: refuse derived fuel. FE: Ferrous metals. NFE: Non-ferrous metals. C sequestered refers to the carbon stored in landfill after the considered 100 years horizon. Values rounded to 2 significant digits. Experimental data.

Figure 2. Characterized environmental impacts on selected non-toxic categories: process contributions. a: waste-specific model results; b: waste-average model results

Figure 3. Characterized environmental impacts on selected toxic categories: process contributions. a: waste-specific model results; b: waste-average model results

Figure 4. Environmental consequences (selected non-toxic categories) associated with the potentially improved waste management scenarios ( $\mathrm{i}$ and ii). The error bars indicate the net difference in the environmental impact or saving between the improved and the baseline scenario (i.e. $\Delta$ saving or $\Delta$ impact $=$ improved value - baseline value). Model results.

Figure 4(cont.). Environmental consequences (selected toxic categories) associated with the potentially improved waste management scenarios (i and ii). The error bars indicate the net difference in the environmental impact or saving between the improved and the baseline scenario (i.e. $\Delta$ saving or $\Delta$ impact $=$ improved value - baseline value). Model results.

Figure 5. Paramount average GHG savings ( $\mathrm{kg} \mathrm{CO}_{2}$-eq. tonne ${ }^{-1} \mathrm{ww}$ ) associated with $100 \%$ waste material recovery at the MBT or, alternatively, $100 \%$ waste material incineration, relative to the baseline LCA results. REC: $100 \%$ recycling of the selected waste material; INC: $100 \%$ incineration of the selected waste material. The 'square' indicates the GHG saving in the case that $\mathrm{C}$ sequestration was not accounted for in the baseline. Model results 
GW a)

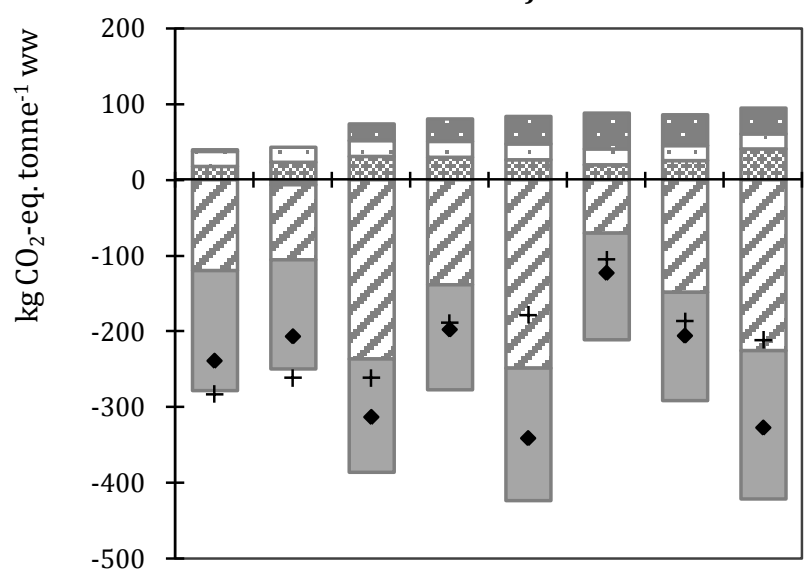

AC a)

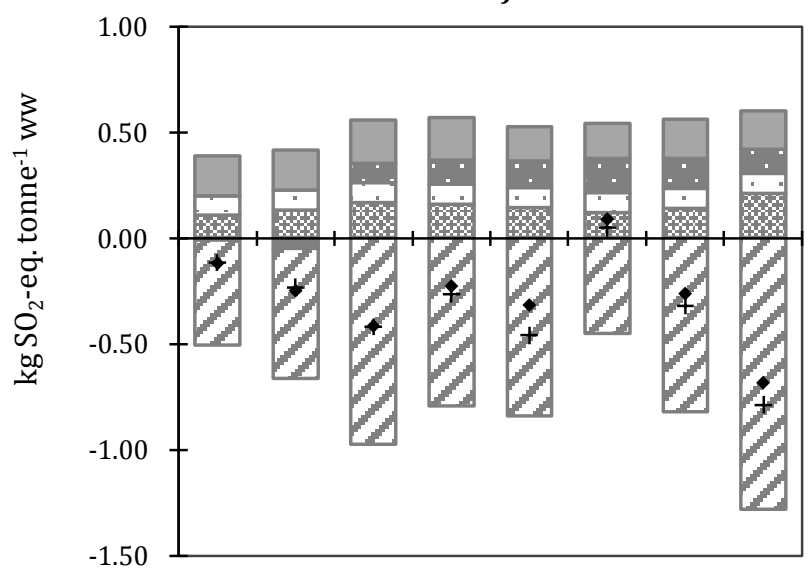

NE a)

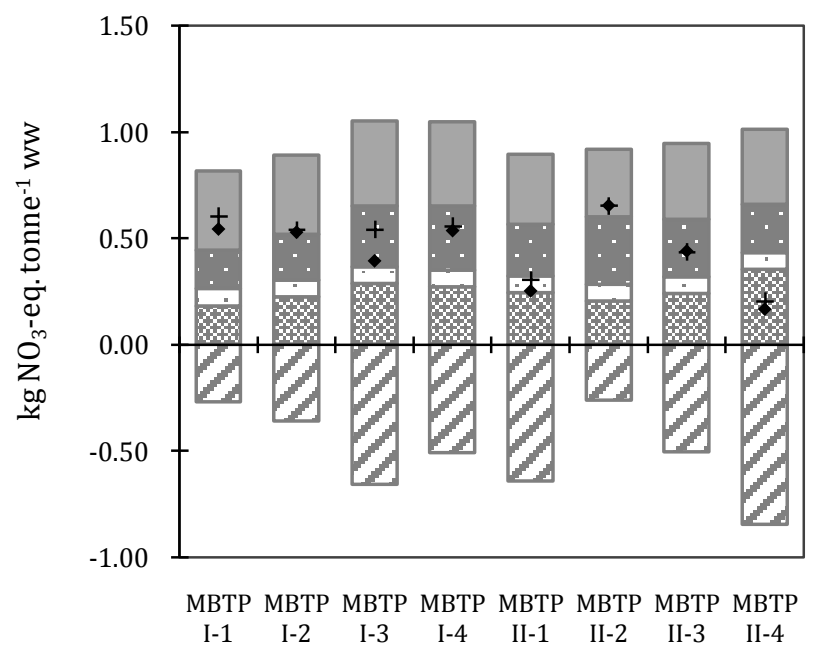

GW b)

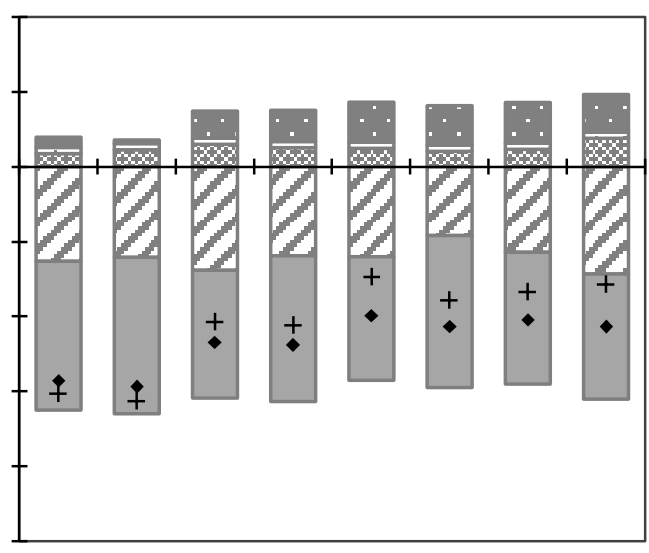

AC b)

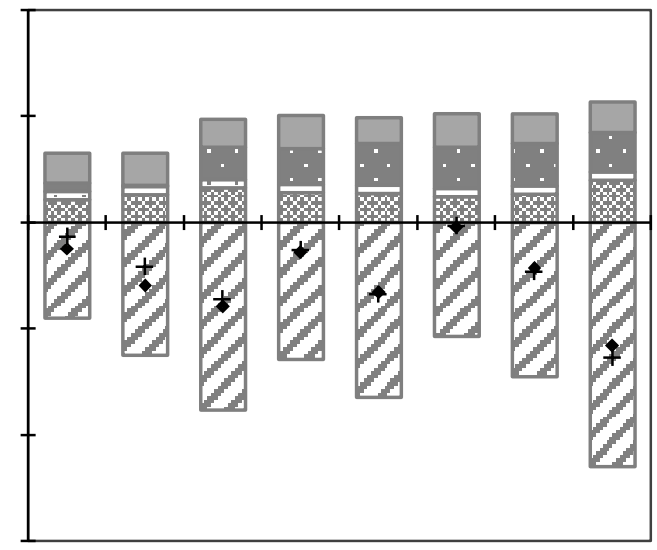

NE b)

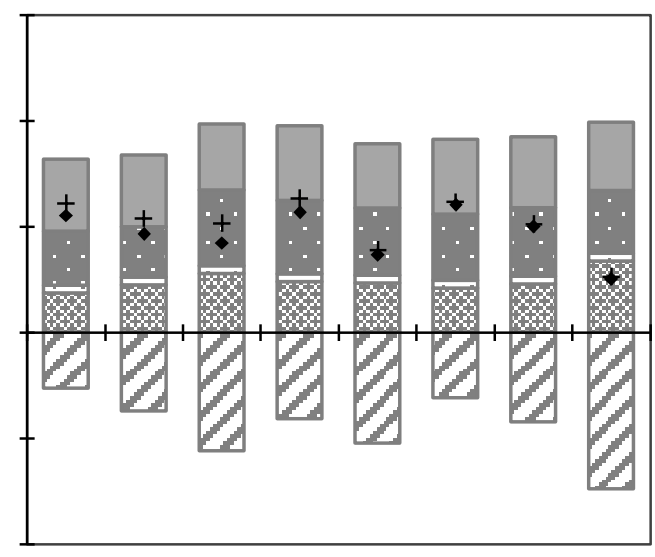

MBTP MBTP MBTP MBTP MBTP MBTP MBTP MBTP

$\begin{array}{llllllll}\text { I-1 } & \text { I-2 } & \text { I-3 } & \text { I-4 } & \text { II-1 } & \text { II-2 } & \text { II-3 } & \text { II-4 }\end{array}$
图 Transportation

$\square$ Recycling

+ Total Coal $\square$ Mechanical treatment Biological processes

$\square$ Landfill

- Total Natural Gas 
ETwc a)
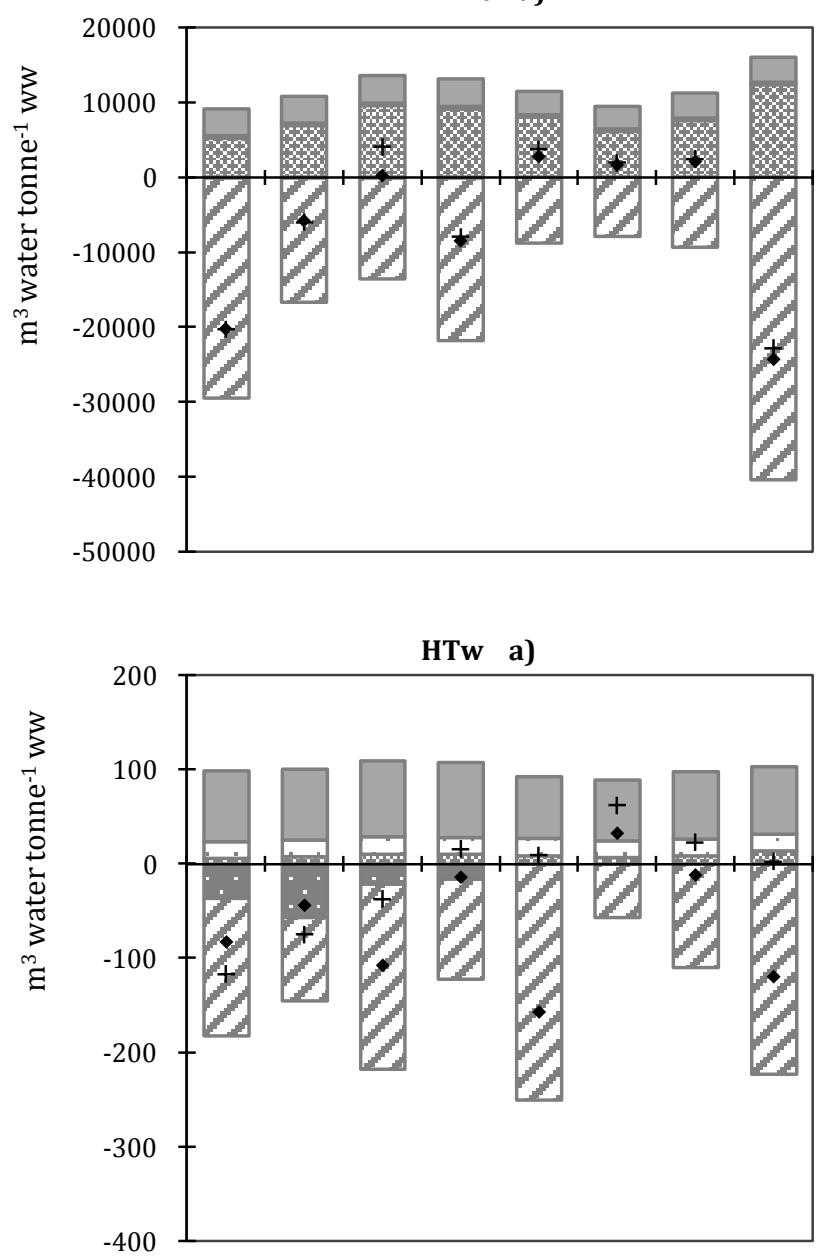

HTs a)

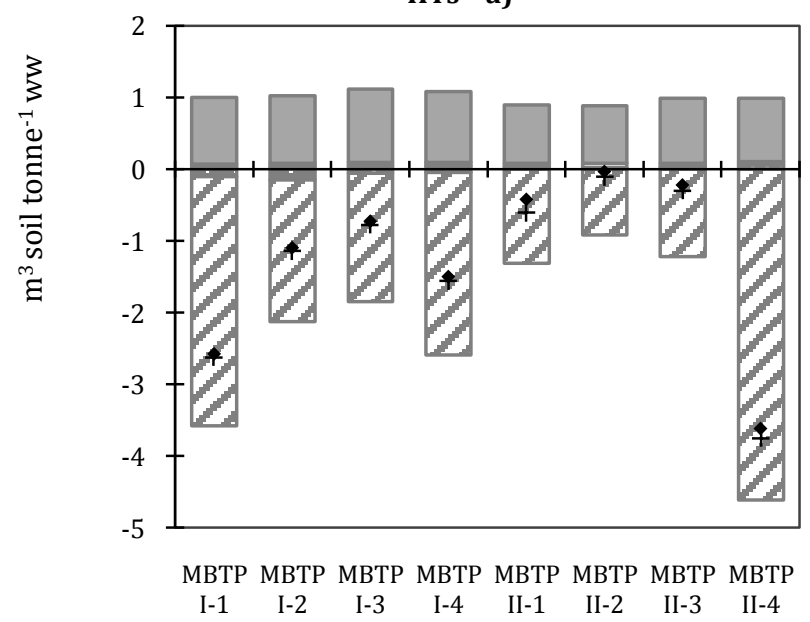

ETwc b)

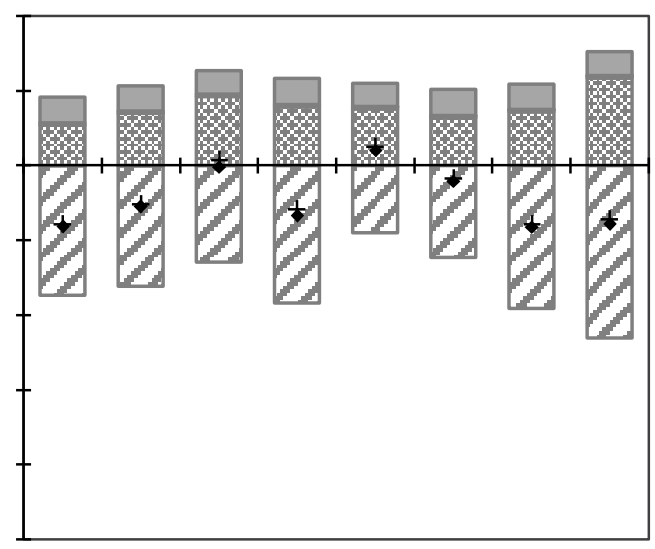

HTw b)

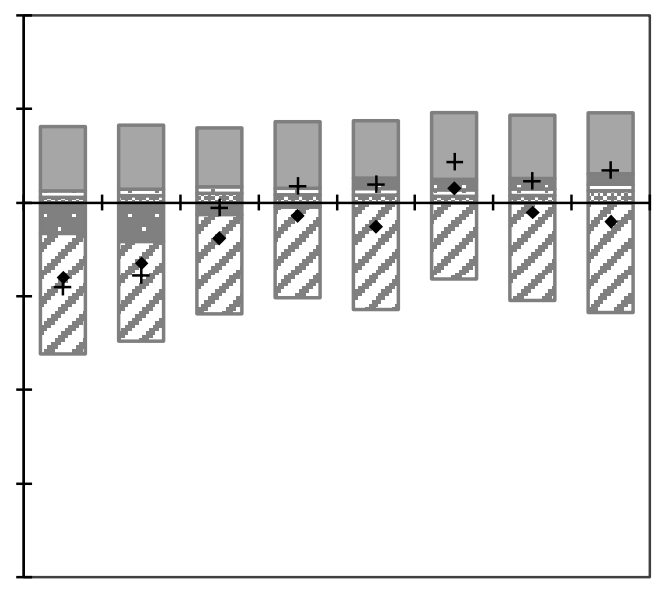

HTs b)

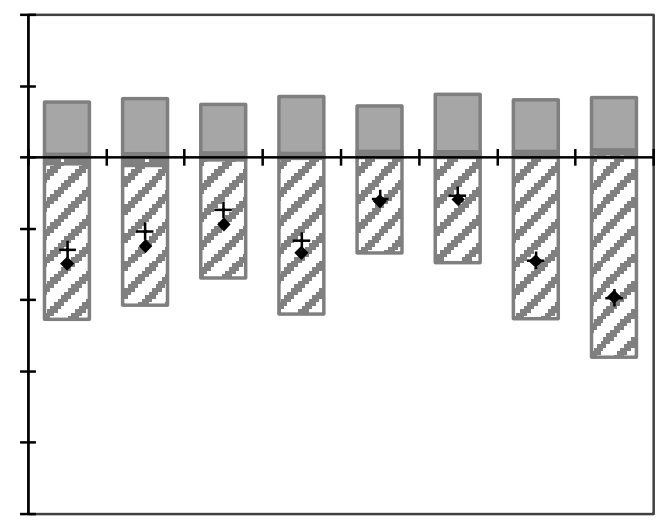

MBTP MBTP MBTP MBTP MBTP MBTP MBTP MBTP $\begin{array}{llllllll}\text { I-1 } & \text { I-2 } & \text { I-3 } & \text { I-4 } & \text { II-1 } & \text { II-2 } & \text { II-3 } & \text { II-4 }\end{array}$

$\begin{array}{lll}\text { ⿴囗大 Transportation } & \square \text { Mechanical treatment } & \cdot \text { Biological processes } \\ \square \text { Recycling } & \square \text { Landfill } & \bullet \text { Total Natural Gas } \\ + \text { Total Coal } & & \end{array}$




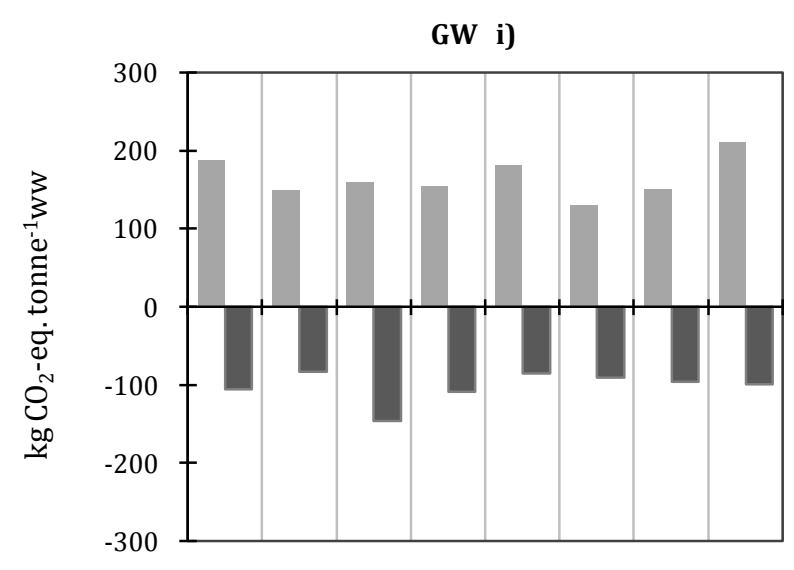

AC i)

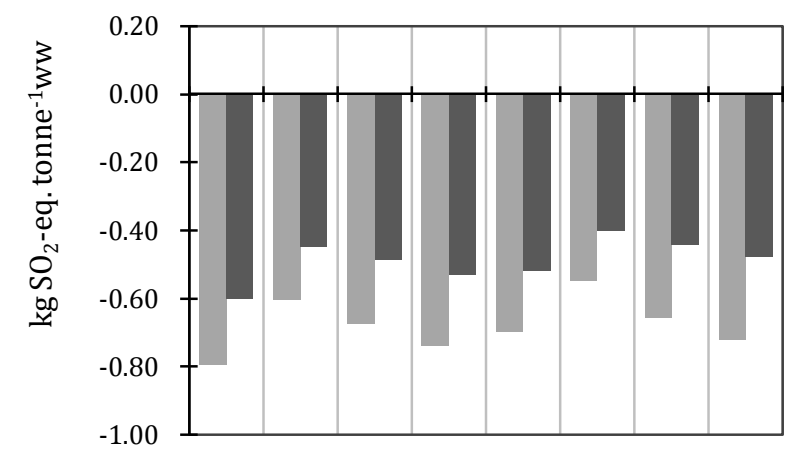

$\mathrm{NE}$ i)

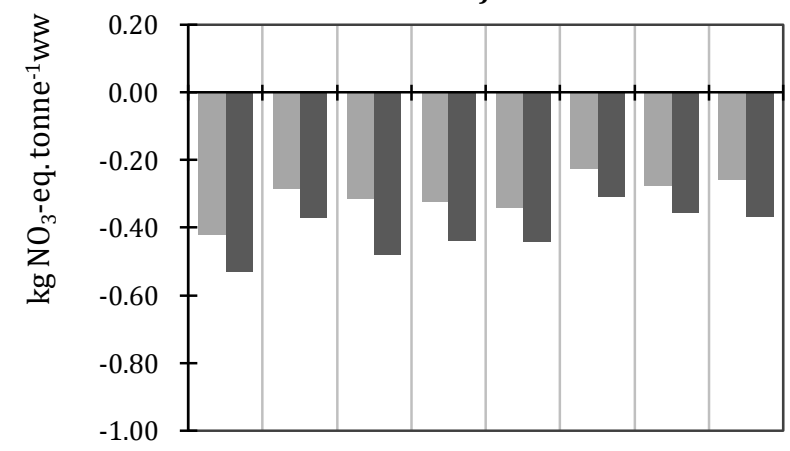

ETwc i)

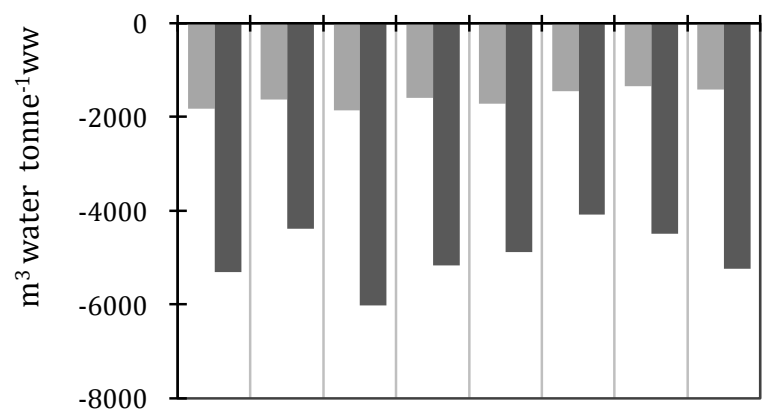

MBTP MBTP MBTP MBTP MBTP MBTP MBTP MBTP $\begin{array}{llllllll}\text { I-1 } & \text { I-2 } & \text { I- } 3 & \text { I-4 } & \text { II- } 1 & \text { II-2 } & \text { II-3 } & \text { II-4 }\end{array}$
GW ii)

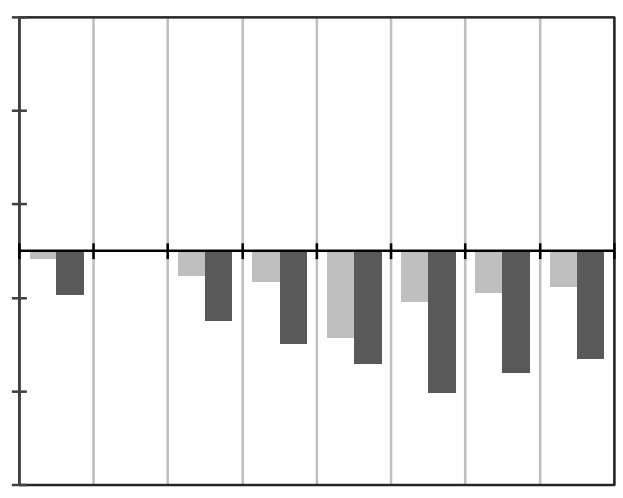

AC ii)

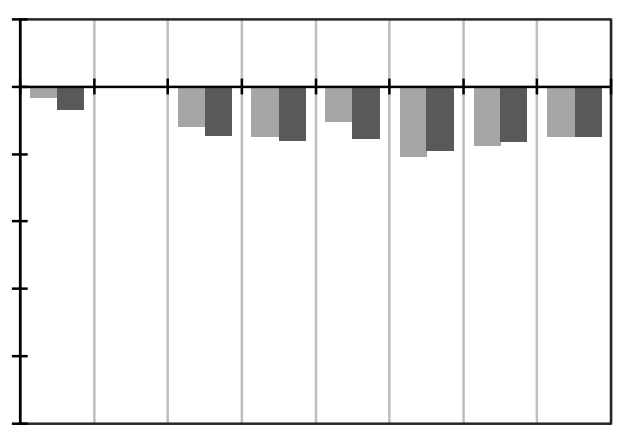

NE ii)

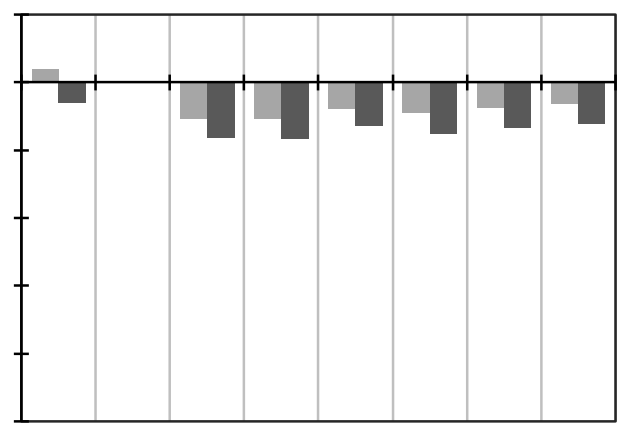

ETwc ii)

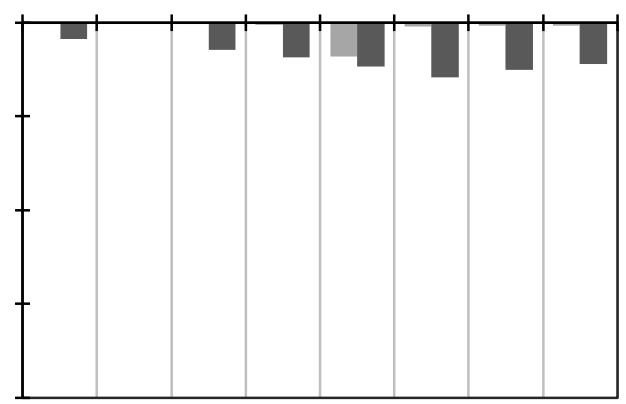

MBTP MBTP MBTP MBTP MBTP MBTP MBTP MBTP

$\begin{array}{llllllll}\text { I-1 } & \text { I-2 } & \text { I-3 } & \text { I-4 } & \text { II-1 } & \text { II-2 } & \text { II-3 } & \text { II-4 }\end{array}$ 
HTw i)

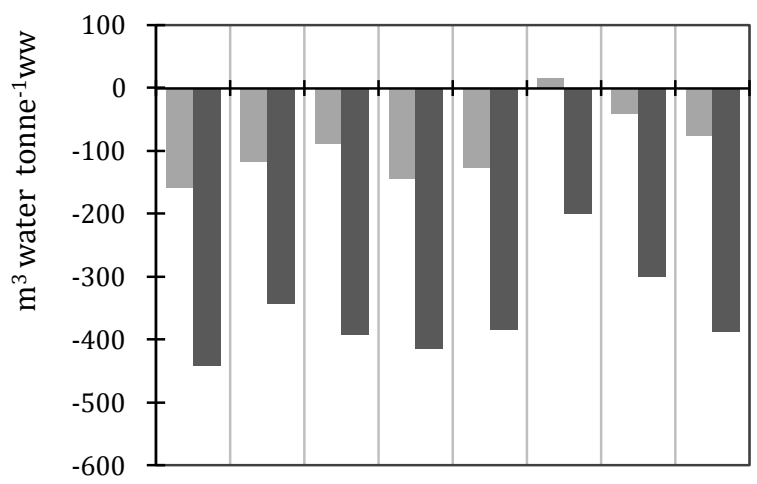

HTs i)

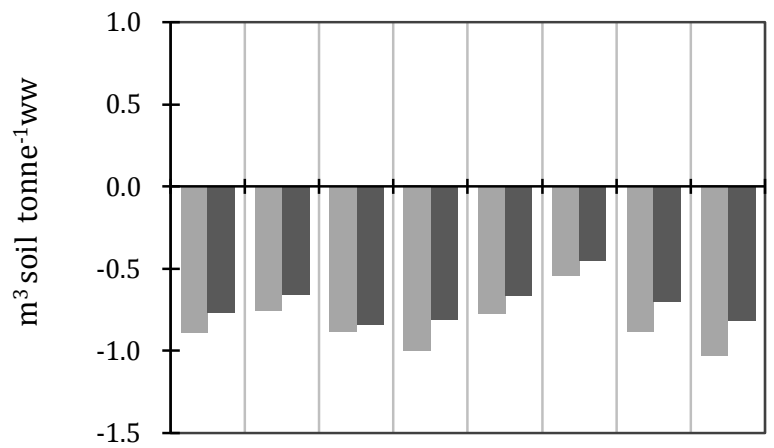

SGR i)

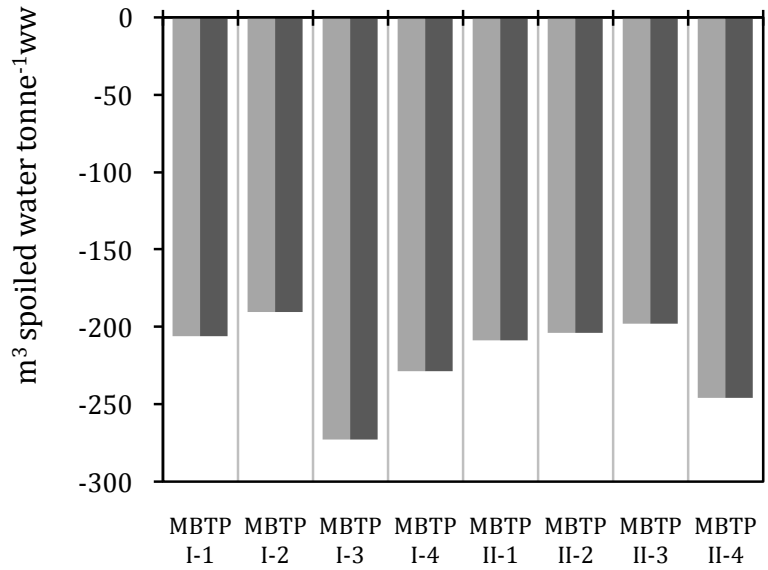

HTw ii)

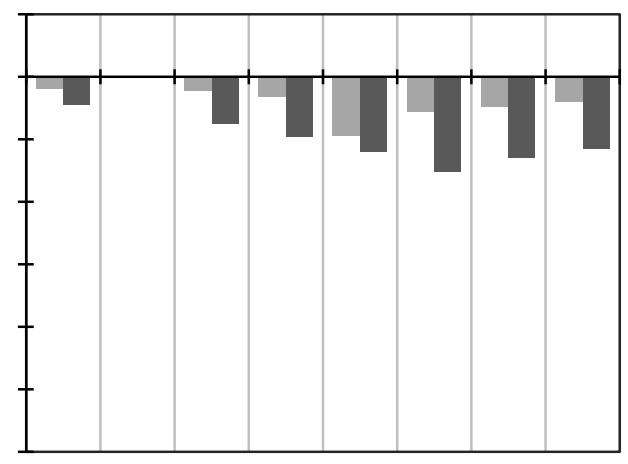

HTs ii)

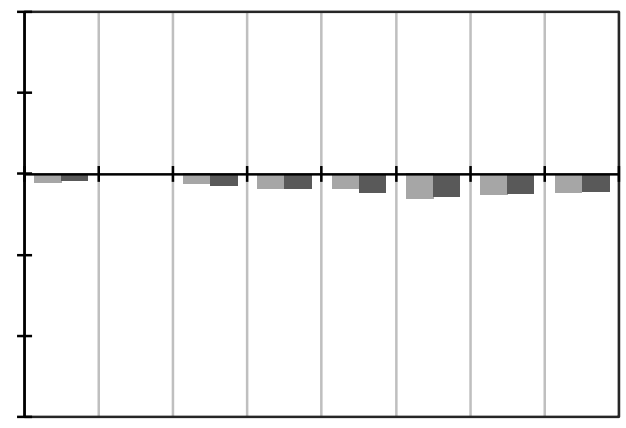

SGR ii)

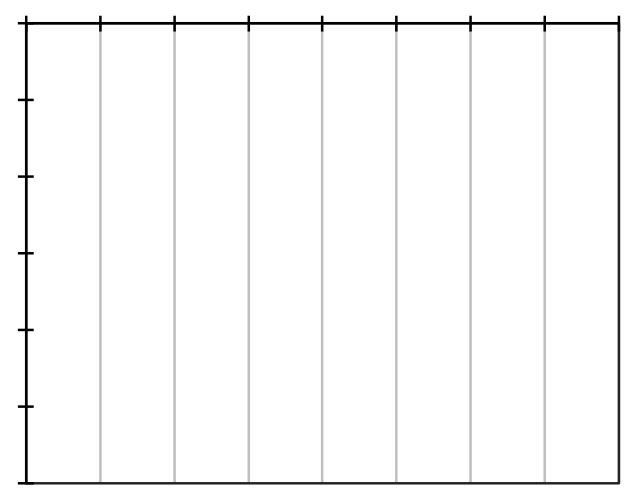

MBTP MBTP MBTP MBTP MBTP MBTP MBTP MBTP $\begin{array}{llllllll}\text { I-1 } & \text { I-2 } & \text { I-3 } & \text { I-4 } & \text { II-1 } & \text { II-2 } & \text { II-3 } & \text { II-4 }\end{array}$ 


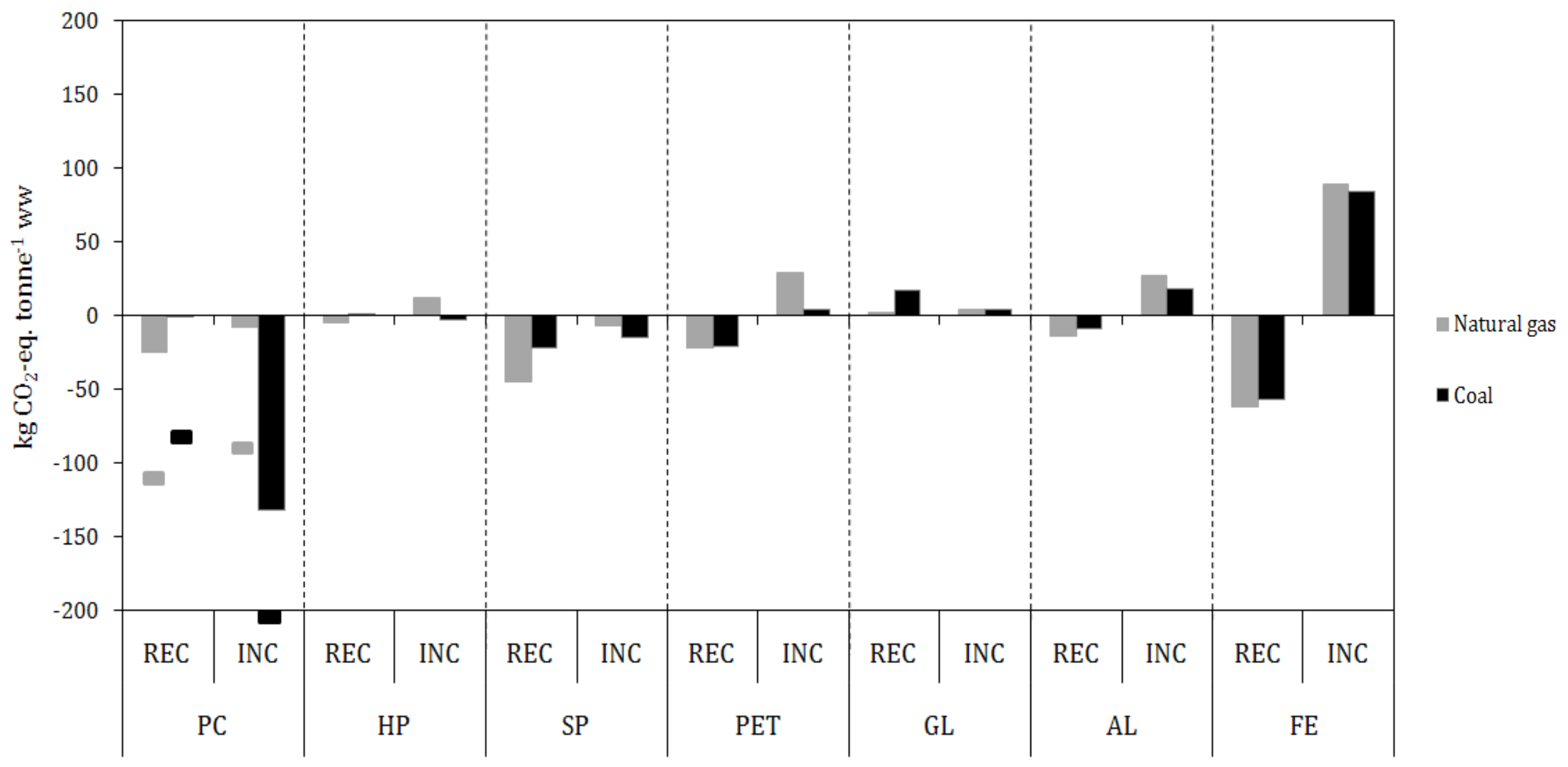




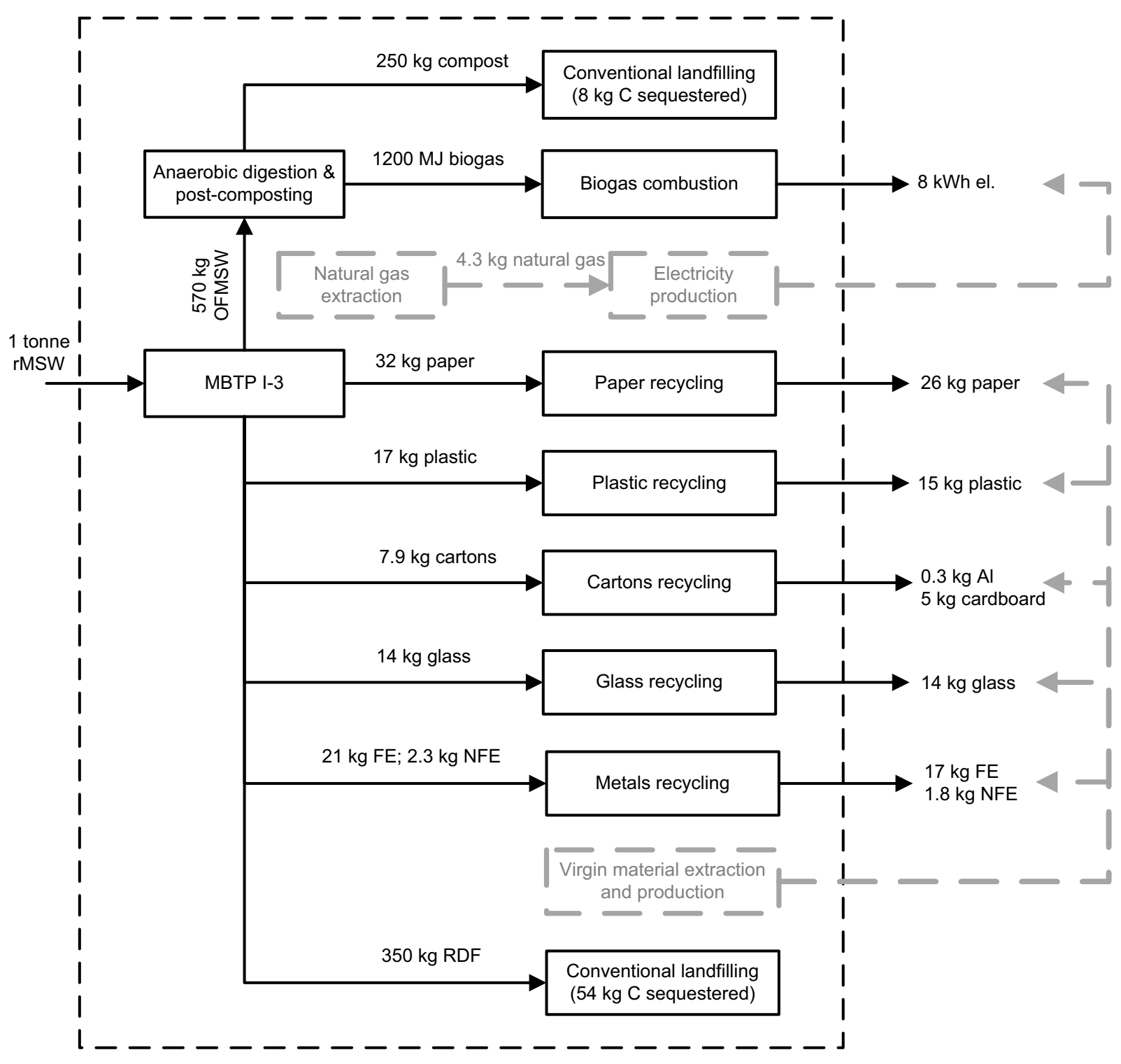


Table 1. Net methane and electricity production at the MBT plants in the LCA scenarios with MBT type I. In MBTP I-3 and MBTP I-4 a share of the biogas is combusted in boiler to heat the reactor. MBTP I-1 and I-2 use waste heat from the gas engine. Values rounded to two significant digits. Data provided from plant operators.

\begin{tabular}{|c|c|c|c|c|}
\hline Scenario & $\begin{array}{r}\mathrm{CH}_{4} \text { production } \\
\left(\mathrm{Nm}^{3} \text { tonne }^{-1} \mathrm{DM}\right)\end{array}$ & $\begin{array}{r}\mathrm{CH}_{4} \text { production } \\
\left(\mathrm{Nm}^{3} \text { tonne }{ }^{-1} \mathrm{WW}\right)\end{array}$ & $\begin{array}{r}\text { Electricity production } \\
\left(\mathrm{kWh} \mathrm{Nm}^{-3}\right)\end{array}$ & $\begin{array}{r}\eta_{\mathrm{el}} \\
(\%)\end{array}$ \\
\hline MBTP I-1 & 110 & 43 & 2.4 & 37 \\
\hline MBTP I-2 & 130 & 52 & 2.3 & 36 \\
\hline MBTP I-3 & 140 & 58 & 0.91 & 14 \\
\hline MBTP I-4 & 110 & 46 & 0.83 & 13 \\
\hline
\end{tabular}


Table 2. Composition of: i) rMSW input to the assessed MBT scenarios and ii) produced RDF (percent in wet basis, $\mathrm{kg} \mathrm{kg}^{-1} \mathrm{ww}$ ). Values rounded to two significant digits. $\left({ }^{*}=\cdot 10^{-2}\right)$. Experimental data.

\begin{tabular}{|c|c|c|c|c|c|c|c|c|c|c|c|c|c|c|c|c|c|}
\hline \multirow[b]{2}{*}{ Waste material fraction } & \multicolumn{9}{|c|}{ rMSW } & \multicolumn{8}{|c|}{ RDF } \\
\hline & $\begin{array}{r}\text { MBTP } \\
\mathrm{I}-1 \\
\end{array}$ & $\begin{array}{r}\text { MBTP } \\
\text { I-2 } \\
\end{array}$ & $\begin{array}{r}\text { MBTP } \\
\text { I-3 } \\
\end{array}$ & $\begin{array}{r}\text { MBTP } \\
\text { I-4 } \\
\end{array}$ & $\begin{array}{r}\text { MBTP } \\
\text { II-1 } \\
\end{array}$ & $\begin{array}{r}\text { MBTP } \\
\text { II-2 } \\
\end{array}$ & $\begin{array}{r}\text { MBTP } \\
\text { II-3 } \\
\end{array}$ & $\begin{array}{r}\text { MBTP } \\
\text { II-4 } \\
\end{array}$ & $\begin{array}{l}\text { CYL } \\
2010 \\
\end{array}$ & $\begin{array}{r}\text { MBTP } \\
\text { I-1 } \\
\end{array}$ & $\begin{array}{r}\text { MBTP } \\
\text { I-2 } \\
\end{array}$ & $\begin{array}{r}\text { MBTP } \\
\text { I-3 }\end{array}$ & $\begin{array}{r}\text { MBTP } \\
\text { I-4 }\end{array}$ & $\begin{array}{r}\text { MBTP } \\
\text { II-1 } \\
\end{array}$ & $\begin{array}{r}\text { MBTP } \\
\text { II-2 } \\
\end{array}$ & $\begin{array}{r}\text { MBTP } \\
\text { II-3 } \\
\end{array}$ & $\begin{array}{r}\text { MBTP } \\
\text { II-4 } \\
\end{array}$ \\
\hline Organic matter & 61 & 59 & 51 & 55 & 50 & 67 & 55 & 51 & 56 & 14 & 23 & 21 & 28 & 19 & 30 & 24 & 33 \\
\hline Paper and cardboard & 12 & 7.9 & 19 & 10 & 23 & 8.9 & 15 & 16 & 14 & 31 & 28 & 30 & 28 & 24 & 27 & 30 & 27 \\
\hline Hard plastic (HDPE) & 0.6 & 1.2 & 0.9 & 0.9 & 0.5 & 0.6 & 0.6 & 1.0 & 0.7 & 1.7 & 0.9 & 0.8 & 1.4 & 0.6 & 1.5 & 0.1 & 1.0 \\
\hline Plastic bottles (PET) & 1.3 & 1.8 & 1.2 & 1.5 & 1.2 & 1.5 & 2.0 & 1.2 & 1.5 & 2.4 & 2.2 & 1.5 & 3.0 & 1.4 & 1.3 & 1.4 & 2.1 \\
\hline Soft plastic (LDPE) & 5.3 & 4.7 & 5.6 & 7.8 & 4.6 & 3.4 & 5.4 & 5.9 & 5.6 & 17 & 11 & 10 & 12 & 12 & 8.4 & 13 & 6.0 \\
\hline Non-recyclable pl. & 2.7 & 2.5 & 3.8 & 4.3 & 3.1 & 2.0 & 1.7 & 2.5 & 3.0 & 11 & 10 & 10 & 7.2 & 13 & 14 & 9.0 & 13 \\
\hline Glass & 2.5 & 4.0 & 3.0 & 3.1 & 3.1 & 2.5 & 5.2 & 3.9 & 3.3 & 0.2 & 0.8 & 0.5 & 1.0 & 0.3 & 0.0 & 0.1 & 1.0 \\
\hline Ferrous metals & 2.0 & 1.7 & 4.2 & 2.6 & 1.7 & 1.7 & 3.6 & 1.8 & 2.5 & 1.1 & 2.1 & 5.6 & 2.3 & 2.5 & 2.6 & 4.9 & 4.0 \\
\hline Aluminium metals & 0.9 & 0.6 & 0.5 & 0.6 & 0.5 & 0.3 & 0.2 & 0.9 & 0.5 & 0.7 & 0.8 & 0.8 & 0.6 & 1.2 & 0.6 & 0.2 & 0.2 \\
\hline Diapers, sanitary towel & 3.1 & 3.7 & 3.8 & 5.7 & 3.5 & 1.4 & 4.8 & 5.9 & 4.0 & 6.5 & 8.0 & 6.6 & 4.5 & 7.1 & 4.7 & 4.2 & 5.3 \\
\hline Beverage cartons & 1.1 & 0.9 & 1.2 & 1.6 & 0.9 & 0.9 & 1.3 & 1.7 & 1.2 & 3.4 & 1.3 & 1.4 & 2.3 & 1.3 & 1.1 & 1.4 & 2.1 \\
\hline Textiles and leather & 4.1 & 3.6 & 2.1 & 1.6 & 4.6 & 4.8 & 2.7 & 4.7 & 3.5 & 7.5 & 7.3 & 6.8 & 8.7 & 12 & 5.7 & 11 & 5.0 \\
\hline Wood & 1.1 & 1.3 & 2.0 & 0.7 & 2.1 & 0.3 & 0.6 & 1.3 & 1.1 & 3.5 & 3.7 & 2.7 & 0.8 & 3.4 & 1.8 & 1.6 & 0.3 \\
\hline Disp. sanitary prod. & 0.0 & 0.0 & 0.2 & 0.0 & 0.0 & 0.0 & 0.0 & 1.9 & 0.2 & 0.0 & 0.0 & $7.4^{*}$ & 0.0 & 0.0 & 0.0 & 0.2 & 0.0 \\
\hline Batteries & 0.0 & 0.0 & $2.1^{*}$ & 0.0 & 0.0 & $7.4^{*}$ & $2.8^{*}$ & 0.0 & $1.4^{*}$ & 0.0 & 0.0 & 0.0 & 0.0 & 0.0 & 0.0 & 0.0 & 0.0 \\
\hline Yard wastes & 2.0 & 6.4 & 1.8 & 2.7 & 0.0 & 2.1 & 1.2 & 0.2 & 2.1 & 0.5 & 0.0 & 0.0 & 0.0 & 0.6 & 0.0 & 0.0 & 0.0 \\
\hline Electronics (small WEEE) & 0.4 & $5.7^{*}$ & 0.0 & $3.5^{*}$ & $4.6^{*}$ & 0.0 & 0.2 & 0.2 & 0.1 & 0.0 & 0.6 & 1.3 & 0.3 & 0.0 & 0.5 & 0.2 & $4.3^{*}$ \\
\hline Non-combustible & 0.4 & 0.5 & 0.0 & 1.2 & 1.1 & 2.7 & 0.0 & 0.5 & 0.7 & 0.0 & 0.0 & 0.2 & 0.0 & 1.5 & 0.4 & 0.0 & 0.0 \\
\hline TOTAL & 100 & 100 & 100 & 100 & 100 & 100 & 100 & 100 & 100 & 100 & 100 & 100 & 100 & 100 & 100 & 100 & 100 \\
\hline
\end{tabular}


Table 3. Recovery efficiencies (percent in wet basis, $\mathrm{kg} \mathrm{ww}$ recovered $\mathrm{kg}^{-1} \mathrm{ww}$ input): percent of individual waste materials (e.g. hard plastic, paper and cardboard, etc.) recovered at the assessed MBT plants. Values rounded to two significant digits. Experimental data.

\begin{tabular}{lrrrrrrrr}
\hline \multirow{2}{*}{ Waste material fraction } & MBTP & MBTP & MBTP & MBTP & MBTP & MBTP & MBTP & MBTP \\
& I-1 & I-2 & I-3 & I-4 & II-1 & II-2 & II-3 & II-4 \\
\hline Organic matter & 93 & 90 & 87 & 85 & 89 & 90 & 87 & 81 \\
Paper and cardboard & 1.1 & 0.2 & 17 & 1.0 & 39 & 0.5 & 2.2 & 32 \\
Hard plastic (HDPE) & 0.7 & 24 & 34 & 2.7 & 8.7 & 1.5 & 4.6 & 36 \\
Plastic bottles (PET) & 11 & 28 & 33 & 4.9 & 43 & 40 & 48 & 24 \\
Soft plastic (LDPE) & 0.4 & 10 & 31 & 39 & 6.0 & 1.4 & 8.8 & 60 \\
Glass & 12 & 12 & 4.7 & 4.6 & 49 & 5.0 & 8.0 & 9.3 \\
Ferrous metals & 84 & 68 & 58 & 74 & 54 & 57 & 60 & 35 \\
Aluminium metals & 77 & 61 & 47 & 72 & 33 & 42 & 72 & 95 \\
Beverage cartons & 9.6 & 60 & 65 & 57 & 56 & 65 & 71 & 65 \\
\hline
\end{tabular}


Supporting information
Click here to download e-component: Supporting Information_revised_v3.docx

Supporting information
Click here to download e-component: Supporting Information_revised_v3.docx

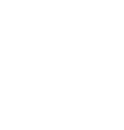
$\sqrt{10}$

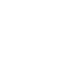

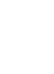
.

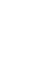
.

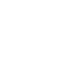
.

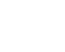

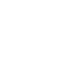

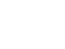

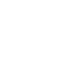

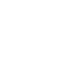

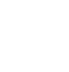

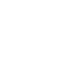

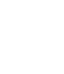

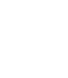

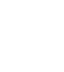

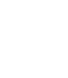

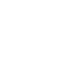

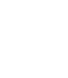

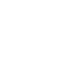

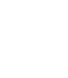

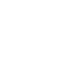

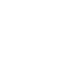

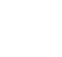


Supplementary data (SD) for:

Journal of Environmental Management

\section{Mechanical-biological treatment: performance and potentials. An LCA of 8 MBT plants including waste characterization}

Cristina Montejo $*^{\mathrm{a}}$, Davide Tonini ${ }^{\mathrm{b}}$, María del Carmen Márquez ${ }^{\mathrm{a}}$, Thomas Fruergaard Astrup ${ }^{\mathrm{b}}$

a Department of Chemical Engineering, University of Salamanca, Plaza de los Caídos 1-5, 37008 Salamanca, Spain.

${ }^{\mathrm{b}}$ Department of Environmental Engineering, Technical University of Denmark, Miljoevej, Building 115, 2800 Kgs. Lyngby, Denmark.

*Corresponding author. Tel: +34 923294 479; Fax: +34 923294 574. E-mail: cmontejo@usal.es

This SD document includes text, tables, and equations with details on the life cycle inventory of the waste treatment technologies used in the assessment and on the LCA results. 


\section{Table of Contents}

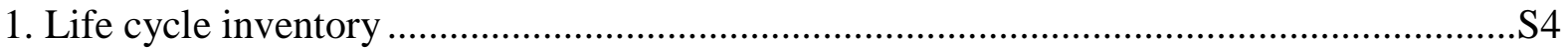

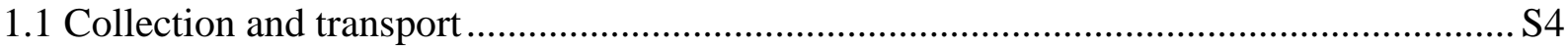

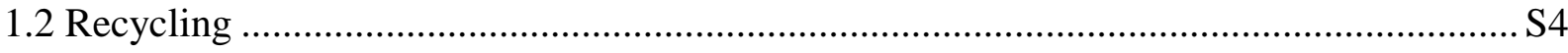

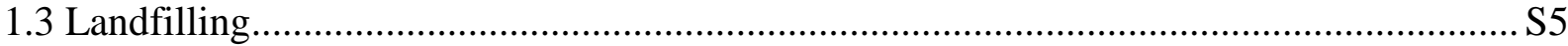

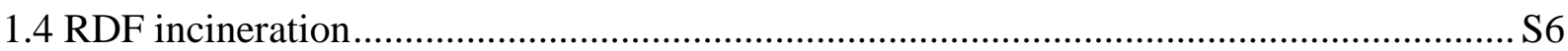

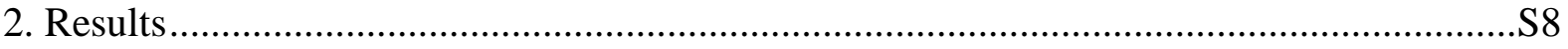

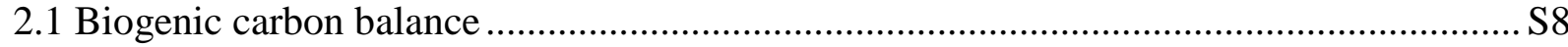

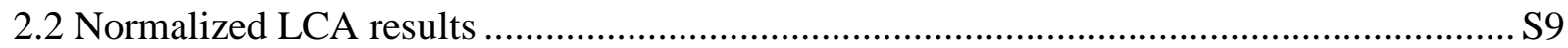

2.3 Potential GHG savings from recovery/recycling .......................................................... S11

2.4 Energy from RDF (break-even points): mathematical approach ..................................... S12

2.5 Estimation of overall potential for GHG savings by optimizing MBT plants .................. S15

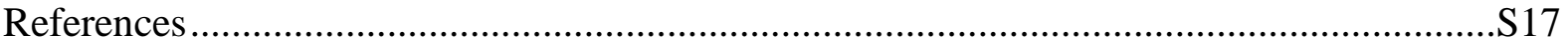




\section{Life cycle inventory}

\subsection{Collection and transport}

Collection was modelled by its diesel consumption per tonne of wet waste collected (3.27 L diesel tonne ${ }^{-1}$ ww) according to Larsen et al. (2009a). Each recyclable fraction mechanically recovered in the MBT plant was baled, stored separately, and sent to recycling facilities. The fuel consumption for transportation to the recycling plants was modelled based on Eisted et al. (2009). The fuel consumption ranged from $0.04 \mathrm{~L}_{\text {diesel }} \mathrm{km}^{-1}$ tonne $\mathrm{e}^{-1} \mathrm{RDF}$ to $0.2 \mathrm{~L}$ diesel $\mathrm{km}^{-1}$ tonne $\mathrm{e}^{-1}$ plastic. Distances were based on current destination of the recovered products which are $200 \mathrm{~km}$ for glass, $250 \mathrm{~km}$ for paper, $300 \mathrm{~km}$ for metals, $700 \mathrm{~km}$ for transportation of both plastics and beverage cartons, and $2 \mathrm{~km}$ for transport of compost, rejects, and RDF to the landfill.

\subsection{Recycling}

Each individual waste material fraction recovered in the MBT plants was assigned a specific recycling technology. The recycling processes were modelled by implementing a combination of two parameters: technical substitution and market substitution. The percentage of technical substitution represents the material loss in the recycling process since losses occur during processing. The amount of recycled material is thus a percentage of the input waste material. The percentage of market substitution is related to the market acceptance of the recycled product. Recycled materials substitute similar products made with virgin material avoiding impacts generated by the original manufacturing; the market substitution is thus estimated as a percentage of the avoided production.

Paper and aluminium recycling technologies were based on generic European data (EDIP database). The material loss during the processes was set to $18 \%$ and $21 \%$ respectively and market substitution was set to $100 \%$ for both materials according to Schmidt and Strömberg (2006). Technologies for plastic recycling were based on data from existing facilities in Denmark and Sweden. HDPE and LDPE substituted for similar materials produced from virgin resources with an efficiency of $90 \%$ and the material loss reached $10 \%$. In the case of PET, recycled material avoided 100\% virgin production and technical substitution was set to $97 \%$, i.e. $3 \%$ of material was lost during the process. A glass recycling technology based on remelting of glass cullet to manufacture new bottles was selected. Both technical and market substitutions were assumed 100\%. Ferrous materials recovered through magnets in MBT plants are shredded and new sheets are made from the scraps; process and 
consumption were based on a Swedish facility. Steel losses were set to $13 \%$ and the market substitution to $100 \%$. The data of these processes were taken from the EDIP database. Additionally, energy and GHG performances of these recycling processes can be found in: Merrild et al. (2009) for paper and cardboard, Astrup et al. (2009a) and Bernstad et al. (2011) for different plastic materials, Damgaard et al. (2009) for metals, Larsen et al. (2009b) for glass.

With respect to beverage cartons, these were assumed composed of 74\% paper, $22 \%$ polyethylene and 4\% aluminium (Tetra Pak, 2004). The first step in recycling is to divide the recovered cartons into their individual components. To this purpose, a process similar to paper repulping is performed recovering the paper fraction by means of water addition. However, process efficiency is lower than original repulping because of the presence of polymer and aluminium layers. Beverage carton fiber has desirable properties and can be made into folding boxboard, corrugation fluting, and other products. The cardboard market substitution was set to $90 \%$. The mixed stream of polyethylene and aluminium is subjected to pyrolysis processes recovering thus aluminium powder which market substitution was assumed $100 \%$. The heat resulting from pyrolysis is used to dry the paper fibers. The overall material loss in the processes was $22 \%$ corresponding to the plastic content of beverage

cartons. The energy consumption was set to $75 \mathrm{kWh}$ tonne $\mathrm{e}^{-1}$ of beverage cartons based on the life cycle inventory of containers systems for wine (Franklin, 2006).

For example with respect to GHG emission savings the net (i.e. including the environmental burdens of the recycling process itself) $\mathrm{CO}_{2}$-eq. savings associated with recycling 1 tonne of, respectively, aluminium, ferrous metal, paper, hard and soft plastic, plastic bottles, glass, and beverage cartons equalled (assuming natural gas as marginal) 8200, 5800, 720, 1200, 2400, 680, 260, and $1000 \mathrm{~kg} \mathrm{CO}_{2}$-eq. tonne ${ }^{-1}$ ww.

\subsection{Landfilling}

Stabilized organic material (compost), RDF, and rejects from compost refinement were landfilled. The landfill was modelled as a conventional landfill (Manfredi and Christensen, 2009). This technology involved suitable collection systems of leachate generated because of degradation, leachate treatment process, gas collection system, flaring and oxidizing compost layer on the top of the landfilled waste. The assessed 100-year horizon was divided in four time periods to better represent the different operational conditions of the landfill cells (Manfredi and Christensen, 2009). It was assumed that $80 \%$ of the landfill gas generated was collected during the second (duration: 8 years) and third period (duration: 35 years) whilst 
was not collected in the first (duration: 2 years) and last (duration: 55 years). $100 \%$ of the collected gas was assumed burnt in the flare as this is the current management scenario in the geographical region assessed. Composition of leachate and landfill gas was defined according to previous studies (Manfredi and Christensen, 2009).

\subsection{RDF incineration}

Although in the assessed reference scenarios RDF was landfilled (in accordance with the current waste management system in the assessed geographical region), potential changes in RDF management have been studied. This translated into dedicated incineration of RDF in place of the current landfilling.

The incinerator was modelled based on the technology described in Tonini and Astrup (2012). The incinerator was assumed being a grate-fired incinerator equipped with wet flue gas cleaning, selective non-catalytic reduction (SNCR) of $\mathrm{NO}_{\mathrm{x}}, \mathrm{Hg}$ and dioxin removal by activated carbon. The gross electricity efficiency of the incinerator was assumed $30 \%$, relative to the lower heating value (LHV) of the waste input, representing state-of-the-art incinerators combusting high-energy content materials and provided with flue-gas condensation (DEA, 2012, ISWA, 2006). Internal electricity consumption at the plant was 65 $\mathrm{kWh}$ tonne $\mathrm{e}^{-1} \mathrm{ww}$ plus an additional $0.42 \mathrm{~L}_{\text {tonne }}{ }^{-1} \mathrm{ww}$ of oil as auxiliary fuel, and $0.66 \mathrm{~kg}$ $\mathrm{NaOH}$ tonne ${ }^{-1}$ ww and $7.9 \mathrm{~kg} \mathrm{CaCO}_{3}$ tonne $^{-1}$ ww for flue gas cleaning (Astrup et al., 2009b; Fruergaard and Astrup, 2011). The air emissions were divided into process-specific (independent on waste composition, e.g. $\mathrm{NO}_{x}, \mathrm{SO}_{2}, \mathrm{CO}$ ) and waste-specific (determined by output transfer coefficients). Selected air emissions can be found in Tonini and Astrup (2012). Bottom ashes were assumed utilized as construction material substituting natural gravel following the approach of Birgisdottir et al. (2007). Air pollution control (APC) residues were assumed to be utilized in the backfilling of old salt mines following the approach of Fruergaard et al. (2010). 


\section{Results}

\subsection{Biogenic carbon balance}

Table S1 details the biogenic carbon balance for the scenarios under assessment.

Table S1. Biogenic carbon balance from model results (kg C); rMSW: residual MSW input to the MBT plant; RDF: refuse derived fuel; CP: composted material (including rejects); Loss: biogenic C degraded (or found in recycled materials); a: waste-specific results; b: waste-average results.

\begin{tabular}{|c|c|c|c|c|c|c|c|c|c|c|c|c|}
\hline \multirow{3}{*}{ MBTP } & \multirow{2}{*}{\multicolumn{2}{|c|}{ rMSW }} & \multicolumn{4}{|c|}{ Outputs of MBT } & \multicolumn{4}{|c|}{ Sequestration in landfill } & \multirow{2}{*}{\multicolumn{2}{|c|}{ Loss }} \\
\hline & & & & & & & RI & & & & & \\
\hline & $\mathrm{a}$ & b & a & $\mathrm{b}$ & $\mathrm{a}$ & b & $\mathrm{a}$ & $\mathrm{b}$ & $\mathrm{a}$ & $\mathrm{b}$ & $\mathrm{a}$ & $\mathrm{b}$ \\
\hline I-1 & 183 & 183 & 71 & 77 & 39 & 37 & 53 & 58 & 9 & 8 & 121 & 117 \\
\hline $\mathrm{I}-2$ & 176 & 183 & 68 & 87 & 37 & 33 & 50 & 63 & 9 & 8 & 117 & 112 \\
\hline I-3 & 190 & 183 & 75 & 68 & 36 & 37 & 54 & 50 & 8 & 8 & 128 & 125 \\
\hline $\mathrm{I}-4$ & 169 & 183 & 72 & 84 & 33 & 34 & 50 & 60 & 8 & 8 & 111 & 116 \\
\hline II-1 & 206 & 183 & 73 & 62 & 35 & 35 & 55 & 47 & 8 & 8 & 143 & 128 \\
\hline II-2 & 176 & 183 & 65 & 87 & 38 & 33 & 46 & 62 & 9 & 8 & 121 & 113 \\
\hline II-3 & 181 & 183 & 69 & 70 & 38 & 39 & 49 & 51 & 9 & 9 & 123 & 123 \\
\hline II-4 & 190 & 183 & 88 & 74 & 29 & 32 & 65 & 51 & 7 & 7 & 112 & 125 \\
\hline
\end{tabular}




\subsection{Normalized LCA results}

The normalized LCA results (for both waste-specific and waste-average scenarios) are reported in Table S3. Table S2 reports the EU-15 normalization references used to calculate the normalized LCA results (expressed in the unit: $\mathrm{mPE}$ tonne ${ }^{-1} \mathrm{ww}$ ). One PE corresponds to the environmental load caused by one average EU-15 citizen in one year covering all activities in life.

Table S2. Normalization references in the LCA method EDIP97 (Stranddorf et al., 2005).

\begin{tabular}{|c|c|c|c|c|}
\hline Category & Acronym & $\begin{array}{r}\text { Physical } \\
\text { basis }\end{array}$ & $\begin{array}{l}\text { Normalization } \\
\text { reference EU-15 }\end{array}$ & Unit \\
\hline Global warming & GW & Global & 8,700 & $\mathrm{~kg} \mathrm{CO}_{2}$-eq. person ${ }^{-1} \mathrm{y}^{-1}$ \\
\hline Photochemical ozone formation & POF & Regional & 25 & $\mathrm{~kg} \mathrm{C}_{2} \mathrm{H}_{4}$-eq. person ${ }^{-1} \mathrm{y}^{-1}$ \\
\hline Stratospheric ozone depletion & SOD & Global & 0.103 & kg CFC-11-eq. person ${ }^{-1} \mathrm{y}^{-1}$ \\
\hline Acidification & $\mathrm{AC}$ & Regional & 74 & $\mathrm{~kg} \mathrm{SO}_{2}$-eq. person ${ }^{-1} \mathrm{y}^{-1}$ \\
\hline Nutrient enrichment & NE & Regional & 119 & $\mathrm{~kg} \mathrm{NO}_{3}$-eq. person ${ }^{-1} \mathrm{y}^{-1}$ \\
\hline Ecotoxicity in soil & ETs & Regional & 964,000 & $\mathrm{~m}^{3}$ soil person ${ }^{-1} \mathrm{y}^{-1}$ \\
\hline Ecotoxicity in water chronic & ETwc & Regional & 352,000 & $\mathrm{~m}^{3}$ water person ${ }^{-1} \mathrm{y}^{-1}$ \\
\hline Human toxicity via soil & HTs & Regional & 127 & $\mathrm{~m}^{3}$ soil person ${ }^{-1} \mathrm{y}^{-1}$ \\
\hline Human toxicity via water & HTw & Regional & 50,000 & $\mathrm{~m}^{3}$ water person ${ }^{-1} \mathrm{y}^{-1}$ \\
\hline Human toxicity via air & HTa & Regional & $60,900,000,000$ & $\mathrm{~m}^{3}$ air person ${ }^{-1} \mathrm{y}^{-1}$ \\
\hline Spoiled groundwater resources & SGR & Regional & 130 & $\mathrm{~m}^{3}$ groundwater person ${ }^{-1} \mathrm{y}^{-1}$ \\
\hline
\end{tabular}


Table S3. Normalized LCA result (mPE tonne ${ }^{-1} \mathrm{ww}$ ) for all the assessed non-toxic and toxic environmental categories. Values rounded to two significant digits. NG/Coal: natural gas/coal as marginal fuel for electricity production. Values rounded to two significant digits.

\begin{tabular}{|c|c|c|c|c|c|c|c|c|c|c|c|c|c|c|c|c|c|c|c|c|c|}
\hline & & \multirow{2}{*}{\multicolumn{2}{|c|}{ GW }} & \multirow{2}{*}{\multicolumn{2}{|c|}{$\mathrm{AC}$}} & \multirow{2}{*}{\multicolumn{2}{|c|}{$\mathrm{NE}$}} & \multirow{2}{*}{\multicolumn{2}{|c|}{ POF }} & \multirow{2}{*}{\multicolumn{2}{|c|}{ SOD }} & \multirow{2}{*}{\multicolumn{2}{|c|}{ SGR }} & \multirow{2}{*}{\multicolumn{2}{|c|}{ ETwc }} & \multirow{2}{*}{\multicolumn{2}{|c|}{ HTa }} & \multirow{2}{*}{\multicolumn{2}{|c|}{ HTs }} & \multirow{2}{*}{\multicolumn{2}{|c|}{ HTw }} \\
\hline & & & & & & & & & & & & & & & & & & & & & \\
\hline & & $\mathrm{a}$ & $\mathrm{b}$ & $\mathrm{a}$ & $\mathrm{b}$ & $\mathrm{a}$ & $\mathrm{b}$ & $\mathrm{a}$ & $\mathrm{b}$ & $\mathrm{a}$ & $\mathrm{b}$ & $\mathrm{a}$ & $\mathrm{b}$ & $\mathrm{a}$ & $\mathrm{b}$ & $\mathrm{a}$ & $\mathrm{b}$ & $\mathrm{a}$ & $\mathrm{b}$ & $\mathrm{a}$ & $\mathrm{b}$ \\
\hline \multirow{2}{*}{ MBTP I-1 } & NG & -27 & -33 & -1.6 & -1.7 & 4.6 & 4.7 & 1.2 & 0.9 & 2.3 & 1.2 & 3,000 & 3,100 & -57 & -23 & 2.0 & 2.1 & -20 & -12 & -1.7 & $\begin{array}{l}-1.6 \\
\end{array}$ \\
\hline & $\mathrm{CO}$ & -33 & -35 & -1.5 & -0.9 & 5.1 & 5.1 & 0.7 & 0.7 & 1.4 & 1.3 & 3,000 & 3,100 & -58 & -22 & 2.0 & 2.2 & -21 & -10 & -2.3 & -1.8 \\
\hline \multirow{2}{*}{ MBTP I-2 } & NG & -24 & -34 & -3.4 & -4.0 & 4.5 & 3.9 & 1.7 & 1.2 & 2.4 & 1.5 & 3,000 & 3,100 & -16 & -16 & 2.5 & 2.5 & -8.6 & -10 & -0.88 & -1.3 \\
\hline & $\mathrm{CO}$ & -30 & -36 & -3.1 & -2.8 & 4.5 & 4.5 & 1.1 & 1.1 & 1.4 & 1.7 & 3,000 & 3,100 & -17 & -15 & 2.4 & 2.5 & -9.0 & -8.2 & -1.5 & -1.6 \\
\hline \multirow{2}{*}{ MBTP I-3 } & NG & -36 & -27 & -5.6 & -5.4 & 3.3 & 3.6 & 1.7 & 1.6 & 2.6 & 1.2 & 3,100 & 3,000 & 0.6 & -0.6 & 3.0 & 2.9 & -5.7 & -7.4 & -2.2 & -0.76 \\
\hline & $\mathrm{CO}$ & -30 & -24 & -5.6 & -4.9 & 4.6 & 4.3 & 2.1 & 1.7 & 1.6 & 1.4 & 3,100 & 3,000 & 12 & 2.1 & 4.2 & 3.1 & -6.1 & -5.8 & -0.74 & -0.12 \\
\hline \multirow{2}{*}{ MBTP I-4 } & NG & -23 & -27 & -3.1 & -1.9 & 4.5 & 4.8 & 2.0 & 1.5 & 2.5 & 1.6 & 3,100 & 3,100 & -24 & -19 & 2.9 & 2.7 & -12 & -11 & -0.31 & -0.29 \\
\hline & $\mathrm{CO}$ & -22 & -24 & -3.5 & -1.8 & 4.7 & 5.3 & 1.7 & 1.6 & 1.6 & 1.8 & 3,100 & 3,100 & -22 & -17 & 3.1 & 2.9 & -12 & -9.2 & 0.32 & 0.34 \\
\hline \multirow{2}{*}{ MBTP II-1 } & NG & -39 & -23 & -4.3 & -4.5 & 2.1 & 3.1 & 1.3 & 1.3 & 1.9 & 1.0 & 2,400 & 2,300 & 7.8 & 5.7 & 2.3 & 2.6 & -3.3 & -4.8 & -3.1 & -0.52 \\
\hline & $\mathrm{CO}$ & -21 & -17 & -6.2 & -4.6 & 2.6 & 3.3 & 1.7 & 1.4 & 1.2 & 1.1 & 2,400 & 2,300 & 11 & 7.1 & 2.8 & 2.7 & -4.8 & -4.6 & 0.19 & 0.39 \\
\hline \multirow{2}{*}{ MBTP II-2 } & NG & -14 & -25 & 1.2 & -0.3 & 5.5 & 5.1 & 1.6 & 1.3 & 2.1 & 1.6 & 2,300 & 2,600 & 4.6 & -5.9 & 2.5 & 2.5 & -0.2 & -4.6 & 0.65 & 0.31 \\
\hline & $\mathrm{CO}$ & -12 & -20 & 0.7 & -0.2 & 5.5 & 5.2 & 1.3 & 1.4 & 1.4 & 1.7 & 2,300 & 2,600 & 5.6 & -5.0 & 2.6 & 2.6 & -0.9 & -4.3 & 1.2 & 0.86 \\
\hline \multirow{2}{*}{ MBTP II-3 } & NG & -24 & -23 & -3.5 & -2.9 & 3.7 & 4.2 & 1.4 & 1.1 & 2.3 & 1.2 & 2,600 & 2,600 & 5.9 & -23 & 2.7 & 2.6 & -1.7 & -11 & -0.23 & -0.21 \\
\hline & $\mathrm{CO}$ & -22 & -19 & -4.3 & -3.1 & 3.7 & 4.3 & 1.2 & 1.2 & 1.4 & 1.4 & 2,600 & 2,600 & 7.1 & -22 & 2.8 & 2.6 & -2.4 & -11 & 0.46 & 0.45 \\
\hline \multirow{2}{*}{ МBTP II-4 } & NG & -38 & -25 & -9.2 & -7.9 & 1.4 & 2.1 & 1.9 & 2.0 & 2.2 & 1.4 & 2,600 & 2,400 & -69 & -22 & 3.1 & 3.3 & -28 & -15 & -2.4 & -0.41 \\
\hline & $\mathrm{CO}$ & -24 & -18 & -11 & -8.6 & 1.7 & 2.2 & 2.2 & 2.1 & 1.6 & 1.5 & 2,600 & 2,400 & -65 & -20 & 3.5 & 3.5 & -30 & -16 & 0.06 & 0.69 \\
\hline
\end{tabular}




\subsection{Potential GHG savings from recovery/recycling}

Table S4 details the potential GHG savings ( $\mathrm{kg} \mathrm{CO}_{2}$-eq. tonne ${ }^{-1} \mathrm{ww}$ ) associated with $100 \%$ waste material recovery or, alternatively, $100 \%$ waste material incineration at the individual MBT scenarios relative to the baseline LCA results. The average GHG savings are displayed in

Figure 5 of the main manuscript.

Table S4. Potential for GHG savings ( $\mathrm{kg} \mathrm{CO}_{2}$-eq. tonne ${ }^{-1} \mathrm{ww}$ ) associated with $100 \%$ waste material recovery or, alternatively, $100 \%$ waste material incineration at the individual MBT scenarios relative to the baseline LCA results. The values are reported for the case of natural gas as marginal electricity source. The results for the case of coal as marginal electricity source are provided only as average of the 8 MBT scenarios (line "Average (CO)"). REC: 100\% recycling of the selected waste material; INC: 100\% incineration of the selected waste material. PC: paper and cardboard; HP: hard plastic (HDPE); SP: soft plastic (LDPE); PET: polyethylene terephthalate; GL: glass; AL: aluminium; FE: ferrous metals. NG: natural gas as marginal electricity source; CO: coal as marginal electricity source. Values rounded to two significant digits. Model results.

\begin{tabular}{|c|c|c|c|c|c|c|c|c|c|c|c|c|c|c|c|c|}
\hline \multirow{2}{*}{ MBTP } & \multicolumn{2}{|l|}{$\mathrm{PC}$} & \multicolumn{2}{|l|}{$\mathrm{PC}^{\mathrm{a}}$} & \multicolumn{2}{|l|}{ HP } & \multicolumn{2}{|l|}{ SP } & \multicolumn{2}{|l|}{ PET } & \multicolumn{2}{|l|}{ GL } & \multicolumn{2}{|l|}{$\mathrm{AL}$} & \multicolumn{2}{|l|}{$\mathrm{FE}$} \\
\hline & REC & INC & REC & INC & REC & INC & REC & INC & REC & INC & REC & INC & REC & INC & REC & INC \\
\hline MBTP I-1 (NG) & -17 & -3.6 & -85 & -72 & -4.9 & 8.5 & -61 & -24 & -27 & 20 & 4.0 & 2.9 & -17 & 58 & -17 & 99 \\
\hline MBTP I-2 (NG) & -1.1 & 7.9 & -57 & -48 & -8.7 & 20 & -48 & -16 & -30 & 35 & 0.5 & 4.7 & -19 & 31 & -30 & 69 \\
\hline MBTP I-3 (NG) & -34 & -13 & -110 & -92 & -4.8 & 16 & -44 & -4.7 & -19 & 25 & 2.3 & 3.0 & -21 & 20 & -100 & 150 \\
\hline MBTP I-4 (NG) & -10 & 1.7 & -71 & -60 & -8.2 & 13 & -55 & 1.0 & -33 & 21 & 2.0 & 3.1 & -13 & 36 & -38 & 110 \\
\hline MBTP II-1 (NG) & -42 & -15 & -100 & -75 & -3.2 & 7.5 & -50 & -18 & -16 & 27 & 5.6 & 6.6 & -27 & 14 & -44 & 55 \\
\hline MBTP II-2 (NG) & -3.3 & 6.9 & -64 & -54 & -4.8 & 8.5 & -38 & -15 & -21 & 33 & 3.5 & 2.5 & -14 & 11 & -41 & 58 \\
\hline MBTP II-3 (NG) & -42 & -25 & -110 & -89 & -4.6 & 8.7 & -57 & -19 & -24 & 48 & -3.0 & 5.6 & -4.2 & 12 & -82 & 130 \\
\hline MBTP II-4 (NG) & -18 & 0.4 & -78 & -60 & -5.4 & 18 & -26 & 16 & -21 & 22 & 0.5 & 4.3 & -3.3 & 71 & -67 & 38 \\
\hline Average (NG) & -25 & -7 & -89 & -72 & -5.0 & 12 & -45 & -7 & -22 & 29 & 2.2 & 4.2 & -14 & 27 & -62 & 90 \\
\hline Average (CO) & -1.0 & -130 & -65 & -200 & 1.0 & -3.3 & -22 & -14 & -20 & 5.3 & 17 & 4 & -9.2 & 18 & -56 & 84 \\
\hline
\end{tabular}

a Without accounting for carbon sequestration from paper/cardboard in landfill in the baseline LCA results. 


\subsection{Energy from RDF (break-even points): mathematical approach}

Follows the list of the equations used to calculate the break-even points for:

$\checkmark$ The net electricity efficiency ( $\eta_{\text {power plant }}$ ) that should be achieved at the dedicated RDF incinerator (or a generic power plant) in order to equal the same GHG savings of the baseline (where plastic along with the remaining RDF is landfilled and carbon from paper and organic is sequestered). This was done according to Eq. S1.

$\checkmark$ The plastic recovery efficiency $\left(\eta_{\text {rec }}\right.$ ) that should be achieved at the individual MBT plants to equal the GHG performance of the baseline (where plastic along with the remaining RDF is landfilled and carbon from paper and organic is sequestered; only sorting of PET, soft, and hard plastic were considered). This was done according to Eq. S2.

$\checkmark$ The specific $\mathrm{CO}_{2}$ emission factor that the 'substituted fuel' $\left(\mathrm{EF}_{\text {fuel }}\right)$ should have in the individual MBT scenarios to equal the GHG performance of the baseline (where plastic along with the remaining RDF is landfilled and carbon from paper and organic is sequestered). This was done according to Eq. S3.

The solutions for Eq. S1-S3 (i.e. break-even points) are summarized in Table S6.

$G H G_{\text {baseline }}=-L H V_{R D F} \cdot R D F \cdot \eta_{\text {power plant }} / 3.6 \cdot E F_{N G}+C_{\text {foss }} \cdot R D F \cdot 44 / 12$

Eq. S1

Where:

GHG $_{\text {baseline: }}$ GHG savings achieved in the baseline (landfilling RDF) $\left(\mathrm{kg} \mathrm{CO}_{2}\right)$

RDF: amount of RDF combusted (kg ww)

$\mathrm{LHV}_{\mathrm{RDF}}$ : LHV of the RDF (MJ kg-1 ww)

$\eta_{\text {power plant }}$ electricity efficiency of the power plant (\%) (unknown)

$\mathrm{EF}_{\mathrm{NG}}$ : assumed GHG emission factor for natural gas $\left(0.49 \mathrm{~kg} \mathrm{CO}_{2}\right.$-eq. $\left.\mathrm{kWh}^{-1}\right)$

$\mathrm{C}_{\text {foss }}$ : $\mathrm{C}$ fossil content in the RDF ( $\left.\mathrm{kg} \mathrm{C} \mathrm{kg}^{-1} \mathrm{ww}\right)$

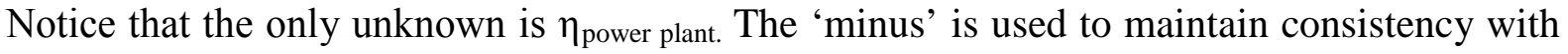
the results discussion (manuscript) where environmental savings are reported as negative values. The $\mathrm{C}_{\text {foss }}$ content of the material fractions constituting the $\mathrm{RDF}$ was assumed according to Riber et al. (2009) as reported in section 2.4 of the manuscript. The terms 3.6 and 44/12 are conversion factors ( $\mathrm{MJ}$ to $\mathrm{kWh}$ and $\mathrm{C}$ to $\mathrm{CO}_{2}$ ). 


$$
\begin{aligned}
& G H G_{\text {baseline }}=-L H V_{R D F^{*}} \cdot R D F^{*} \cdot \eta_{\text {inc }} / 3.6 \cdot E F_{N G}+C_{\text {foss }} \cdot R D F^{*} \cdot 44 / 12 \\
& -\eta_{\text {rec }} \cdot\left(\text { Pot }_{\text {PET recycl }}+\operatorname{Pot}_{S P \text { recycl }}+\operatorname{Pot}_{H P \text { recycl }}\right)
\end{aligned}
$$

Eq. S2

Where:

$\mathrm{GHG}_{\text {baseline: }}$ GHG savings achieved in the baseline (landfilling RDF) $\left(\mathrm{kg} \mathrm{CO}_{2}\right)$

$\mathrm{RDF}^{*}$ : amount of RDF recalculated without the plastic sorted (kg ww)

$\mathrm{LHV}_{\mathrm{RDF}}$ : LHV of the RDF* recalculated without the plastic sorted ( $\left.\mathrm{MJ} \mathrm{kg}^{-1} \mathrm{WW}\right)$

$\eta_{\text {inc }}$ : electricity efficiency of the incinerator (30\%, see section 1.4 of this document)

$\mathrm{EF}_{\mathrm{NG}}$ : assumed GHG emission factor for natural gas $\left(0.49 \mathrm{~kg} \mathrm{CO}_{2}\right.$-eq. $\left.\mathrm{kWh}^{-1}\right)$

$\mathrm{C}_{\text {foss }}$ : C fossil content in the $\mathrm{RDF}^{*}\left(\mathrm{~kg} \mathrm{C} \mathrm{kg}^{-1} \mathrm{ww}\right)$

$\eta_{\text {rec }}$ : recovery efficiency for the plastic material fractions (\%) (unknown)

Pot $_{\mathrm{PET} \text { recycl }}$ : potential GHG saving associated with $100 \%$ recovery of PET ( $\mathrm{kg} \mathrm{CO}_{2}$ tonne $\left.^{-1} \mathrm{ww}\right)$

Pot $_{\text {SP recycl }}$ : potential GHG saving associated with $100 \%$ recovery of soft plastic $\left(\mathrm{kg} \mathrm{CO}_{2}\right.$ tonne $\left.{ }^{-1} \mathrm{ww}\right)$

Pot $_{\mathrm{HP} \text { recycl }}$ : potential GHG saving associated with $100 \%$ recovery of hard plastic $\left(\mathrm{kg} \mathrm{CO}_{2}\right.$ tonne $\left.^{-1} \mathrm{ww}\right)$

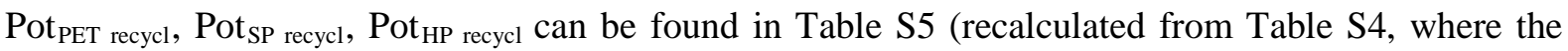

potential GHG savings from recovery/recycling are reported relative to the GHG baseline results, i.e. as net $\Delta \mathrm{CO}_{2}$-eq.).

The only unknown in Equation S2 is $\eta_{\text {rec. }}$ The 'minus' is used to maintain consistency with the text where savings are reported as negative values and impacts as positive.

$$
G H G_{\text {baseline }}=-L H V_{R D F} \cdot R D F \cdot \frac{E F_{\text {fuel }}}{1000}+C_{\text {foss }} \cdot R D F \cdot 44 / 12
$$

Eq. S3

Where:

$\mathrm{GHG}_{\text {baseline }}$ : GHG savings achieved in the baseline (landfilling RDF) $\left(\mathrm{kg} \mathrm{CO}_{2}\right)$

RDF: amount of RDF combusted (kg ww)

$\mathrm{LHV}_{\mathrm{RDF}}$ : LHV of the RDF (MJ kg-1 ww)

$\mathrm{EF}_{\text {fuel }}$ : emission factor of the fuel substituted ( $\mathrm{g} \mathrm{CO}_{2}$-eq. $\mathrm{MJ}^{-1}$ ) (unknown)

$\mathrm{C}_{\text {foss }}$ : C fossil content in the RDF ( $\left.\mathrm{kg} \mathrm{C} \mathrm{kg}^{-1} \mathrm{ww}\right)$

The only unknown in Equation S3 is $\mathrm{EF}_{\text {fuel }} .1000$ is a conversion factor $\left(\mathrm{g} \mathrm{CO}_{2}\right.$ to $\mathrm{kg} \mathrm{CO}_{2}$ ). 
Table S5. Potential for GHG savings ( $\mathrm{kg} \mathrm{CO}_{2}$-eq. tonne ${ }^{-1} \mathrm{ww}$ ) associated with $100 \%$ material recovery of the "recyclable" plastic fractions (i.e. $100 \%$ of the "recyclable share" of each plastic fraction) at the individual MBT scenarios (absolute values, recalculated from Table S4). The values are reported for the case of natural gas as marginal electricity source. HP: hard plastic (HDPE); SP: soft plastic (LDPE); PET: polyethylene terephthalate. Values rounded to two significant digits. Model results.

\begin{tabular}{lccr}
\hline MBTP & HP & SP & PET \\
\hline MBTP I-1 & -4.9 & -61 & -30 \\
MBTP I-2 & -12 & -54 & -42 \\
MBTP I-3 & -8.5 & -65 & -28 \\
MBTP I-4 & -8.5 & -91 & -35 \\
MBTP II-1 & -3.7 & -53 & -28 \\
MBTP II-2 & -4.9 & -39 & -35 \\
MBTP II-3 & -4.9 & -63 & -47 \\
MBTP II-4 & -9.7 & -69 & -28 \\
\hline
\end{tabular}

Table S6. Solutions for Eqs. S1-S3 (break-even points). $\mathrm{EF}_{\text {fuel }}$ : $\mathrm{CO}_{2}$ emission factor of the fuel substituted ( $\mathrm{g} \mathrm{CO}_{2}$-eq. $\mathrm{MJ}^{-1}$ ). $\eta_{\text {power plant }}$ : electricity efficiency (\% relative to LHV); $\eta_{\text {rec }}$ : efficiency of plastic separation (\% input). Note that for $\eta_{\text {rec }}$ a value $>100 \%$ means that the separation of recyclable plastic is not sufficient to equal the GHG savings of the baseline, and additional recovery of nonrecyclable plastic would be needed.

\begin{tabular}{lrrr}
\hline MBTP & $\eta_{\text {power plant }}($ Eq. S1) & $\eta_{\text {rec }}$ (Eq. S2) & EF $_{\text {fuel }}$ (Eq. S3) \\
\hline MBTP I-1 & $52 \%$ & $>100 \%(>67 \%)^{\mathrm{b}}$ & 70 \\
MBTP I-2 & $51 \%$ & $95 \%(78 \%)^{\mathrm{b}}$ & 70 \\
MBTP I-3 & $50 \%$ & $>100 \%(>67 \%)^{\mathrm{b}}$ & 69 \\
MBTP I-4 & $50 \%$ & $90 \%(65 \%)^{\mathrm{b}}$ & 68 \\
MBTP II-1 & $53 \%$ & $>100 \%(>70 \%)^{\mathrm{b}}$ & 72 \\
MBTP II-2 & $49 \%$ & $95 \%(67 \%)^{\mathrm{b}}$ & 67 \\
MBTP II-3 & $49 \%$ & $85 \%(65 \%)^{\mathrm{b}}$ & 67 \\
MBTP II-4 & $50 \%$ & $>100 \%(>72 \%)^{\mathrm{b}}$ & 68 \\
\hline
\end{tabular}

b Overall plastic recovery efficiency (in brackets) calculated on the total plastic input (that is the sum of recyclable and non-recyclable plastic fractions). 


\subsection{Estimation of overall potential for GHG savings by optimizing MBT plants}

Table S7 details the total annual GHG savings that could be achieved in each individual MBT plant under assessment by optimizing biogas-energy and materials recovery (RDF is assumed landfilled). The GHG savings reported for material recovery and biological treatment build on previous results (section 3.3 and Figure 4-5 of the main manuscript).

Table S7. Overall potential for GHG savings in the 8 MBT plants under assessment. NG/CO: natural gas/coal as marginal for electricity production. Values are rounded to two significant digits. Model results.

\begin{tabular}{lrrrrrrr}
\hline \multirow{2}{*}{ MBTP } & \multicolumn{2}{c}{$\begin{array}{c}\text { Material } \\
\text { recovery }\end{array}$} & \multicolumn{2}{c}{$\begin{array}{c}\text { Biological } \\
\text { treatment }\end{array}$} & \multicolumn{2}{r}{$\begin{array}{r}\text { rMSW } \\
\text { treated }\end{array}$} & \multicolumn{2}{r}{$\begin{array}{r}\text { Potential GHG savings } \\
\text { (tonne } \text { CO }_{2} \text {-eq. } \text { - }^{-1} \text { ) }\end{array}$} \\
\cline { 2 - 8 } & NG & \multicolumn{1}{c}{ CO } & NG & \multicolumn{1}{c}{ CO } & tonne $\mathrm{y}^{-1}$ & CO & NG \\
\hline I-1 & -140 & -74 & -8 & -46 & 310,000 & $-47,000$ & $-37,000$ \\
I-2 & -140 & -78 & 0 & 0 & 86,000 & $-12,000$ & $-6,700$ \\
I-3 & -220 & -150 & -26 & -74 & 84,000 & $-21,000$ & $-19,000$ \\
I-4 & -160 & -92 & -33 & -100 & 280,000 & $-53,000$ & $-53,000$ \\
II-1 & -180 & -110 & -93 & -120 & 28,000 & $-7,600$ & $-6,400$ \\
II-2 & -120 & -67 & -54 & -150 & 106,000 & $-19,000$ & $-23,000$ \\
II-3 & -210 & -140 & -45 & -130 & 47,000 & $-12,000$ & $-13,000$ \\
II-4 & -140 & -89 & -38 & -120 & 95,000 & $-17,000$ & $-19,000$ \\
\hline TOTAL & & & & & $1,000,000$ & $-190,000$ & $-180,000$ \\
\hline
\end{tabular}




\section{References}

Astrup, T., Fruergaard, T, Christensen, T.H., 2009a. Recycling of plastics: accounting of greenhouse gases and global warming contributions. Waste Manage Res. 27, 763-772.

Astrup, T., Møller, J., Fruergaard, T., 2009b. Incineration and co-combustion of waste: accounting of greenhouse gases and global warming contributions. Waste Manage Res. 27, 789-799.

Bernstad, A., la Cour Jansen, J., Aspegren, H., 2011. Life cycle assessment of a household solid waste source separation programme: a Swedish case study. Waste Manage. Res. 29(10), 1027-1042.

Birgisdottir, H., Bhander, G., Hauschild, M.Z., Christensen, T.H., 2007. Life cycle assessment of disposal of residues from municipal solid waste incineration: recycling of bottom ash in road construction or landfilling in Denmark evaluated in the ROAD-RES model. Waste Manage. 27, S75-S84.

Damgaard, A., Larsen, A.W., Christensen, T.H., 2009. Recycling of metals: accounting of greenhouse gases and global warming contributions. Waste Manage. Res. 27, 773-780.

DEA, 2012. Danish Energy Agency. Technology data for energy plants - Generation of Electricity and District Heating, Energy Storage and Energy Carrier Generation and Conversion. Danish Energy agency, Copenhagen, Denmark. Available at: http://www.ens.dk/Documents/Netboghandel\%20-

\%20publikationer/2012/Teknologikatalog_2012.pdf (accessed 12.12).

Eisted, R., Larsen, A.W., Christensen, T.H., 2009. Collection, transfer and transport of waste: accounting of greenhouse gases and global warming contribution. Waste Manage. Res. 27, 738-745.

Franklin Associates, 2006. Life cycle inventory of container systems for wine. Final report prepared for Tetra Pak Inc. by Franklin Associates, a division of ERG Prairie village, KS.

Fruergaard, T., Astrup, T., 2011. Optimal utilization of waste-to-energy in an LCA perspective. Waste Manage. 31, 572-582.

Fruergaard, T., Hyks, J., Astrup, T., 2010. Life-cycle assessment of selected management options for air pollution control residues from waste incineration. Sci. Total Environ. 408, 4672-4680.

ISWA, 2006. International Solid Waste Association. Energy from Waste. State of the Art Report. Statistics $5^{\text {th }}$ Edition. Copenhagen, Denmark: ISWA Working Group on Thermal Treatment of Waste. Available at: 
http://www.google.dk/search?q=International+Solid+Waste+Association+(ISWA).+Energy+ from + Waste. + State + of + the + Art + Report. + Statistics +5 th + Edition\&sugexp $=$ chrome, mod $=15 \&$ sourceid=chrome\&ie=UTF-8 $($ accessed 12.12).

Larsen, A.W., Vrgoc, M., Lieberknecht, P., Christensen, T.H., 2009a. Diesel consumption in waste collection and transport and its environmental significance. Waste Manage. Res. 27, 652-659.

Larsen, A.W., Merrild, H., Christensen, T.H., 2009b. Recycling of glass: accounting of greenhouse gases and global warming contributions. Waste Manage. Res. 27, 754-762.

Manfredi, S., Christensen, T.H., 2009. Environmental assessment of solid waste landfilling technologies by means of LCA-modeling (EASEWASTE). Waste Manage. 29, 32-43.

Merrild, H., Damgaard, A., Christensen, T.H., 2009. Recycling of paper: accounting of greenhouse gases and global warming contributions. Waste Manage. Res. 27, 746-753.

Riber, C., Petersen, C., Christensen, T.H., 2009. Chemical composition of material fractions in Danish household waste. Waste Manage. 29, 1251-1257.

Schmidt, A., Strömberg, K., 2006. "Genanvendelse i LCA - systemudvidelse." Rep. No. Miljønyt Nr. 81, Miljøstyrelsen. Available at: http://www2.mst.dk/udgiv/publikationer/2006/87-7052-165-4/pdf/87-7052-166-2.pdf (accessed 12.12).

Stranddorf, H.K., Hoffmann, L., Schmidt, A., 2005. Påvirkningskategorier, normalisering og vægtning i LCA - opdatering af udvalgte UMIP97-data. Danish Ministry of the Environment, Miljønyt n. 77. Available at: http://www2.mst.dk/udgiv/publikationer/2005/87-7614-5727/pdf/87-7614-573-5.pdf (accessed 12.12)

Tetra Pak, 2004. Environmental Report 2004 Sweden. Available on line at: www.corporateregister.com/a10723/tps04-env-swe.pdf (accessed 12.12)

Tonini, D., Astrup, T., 2012. Life-cycle assessment of a waste refinery process for enzymatic treatment of municipal solid waste. Waste Manage. 2012, 32, 165-76. 